\title{
Short- and long-term thermo-erosion of ice-rich permafrost coasts in the Laptev Sea region
}

\author{
F. Günther ${ }^{1}$, P. P. Overduin ${ }^{1}$, A. V. Sandakov ${ }^{2}$, G. Grosse ${ }^{3}$, and M. N. Grigoriev ${ }^{2}$ \\ ${ }^{1}$ Alfred Wegener Institute Helmholtz Centre for Polar and Marine Research, Potsdam, Germany \\ ${ }^{2}$ Melnikov Permafrost Institute, Russian Academy of Sciences, Siberian Branch, Yakutsk, Russia \\ ${ }^{3}$ Geophysical Institute, University of Alaska Fairbanks, Alaska, Fairbanks, USA \\ Correspondence to: F. Günther (frank.guenther@awi.de)
}

Received: 19 January 2013 - Published in Biogeosciences Discuss.: 15 February 2013

Revised: 16 May 2013 - Accepted: 20 May 2013 - Published: 27 June 2013

\begin{abstract}
Permafrost coasts in the Arctic are susceptible to a variety of changing environmental factors all of which currently point to increasing coastal erosion rates and mass fluxes of sediment and carbon to the shallow arctic shelf seas. Rapid erosion along high yedoma coasts composed of Ice Complex permafrost deposits creates impressive coastal ice cliffs and inspired research for designing and implementing change detection studies for a long time, but continuous quantitative monitoring and a qualitative inventory of coastal thermo-erosion for large coastline segments is still lacking. Our goal is to use observations of thermo-erosion along the mainland coast of the Laptev Sea, in eastern Siberia, to understand how it depends on coastal geomorphology and the relative contributions of water level and atmospheric drivers. We compared multi-temporal sets of orthorectified satellite imagery from 1965 to 2011 for three segments of coastline ranging in length from 73 to $95 \mathrm{~km}$ and analyzed thermodenudation (TD) along the cliff top and thermo-abrasion (TA) along the cliff bottom for two nested time periods: longterm rates (the past 39-43 yr) and short-term rates (the past 1-4 yr). The Normalized Difference Thermo-erosion Index (NDTI) was used as a proxy to qualitatively describe the relative proportions of TD and TA. Mean annual erosion rates at all three sites were higher in recent years $\left(-5.3 \pm 1.3 \mathrm{~m} \mathrm{a}^{-1}\right)$ than over the long-term mean $\left(-2.2 \pm 0.1 \mathrm{~m} \mathrm{a}^{-1}\right)$. The Mamontov Klyk coast exhibits primarily spatial variations of thermo-erosion, while intrasite-specific variations caused by local relief were strongest at the Buor Khaya coast, where the slowest long-term rates of around $-0.5 \pm 0.1 \mathrm{~m} \mathrm{a}^{-1}$ were observed. The Oyogos Yar coast showed continuously rapid erosion up to $-6.5 \pm 0.2 \mathrm{~m} \mathrm{a}^{-1}$. In general, variable characteristics of coastal thermo-erosion were observed not only
\end{abstract}

between study sites and over time, but also within single coastal transects along the cliff profile. Varying intensities of cliff bottom and top erosion are leading to diverse qualities of coastal erosion that have different impacts on coastal mass fluxes. The different extents of Ice Complex permafrost degradation within our study sites turned out to influence not only the degree of coupling between TD and TA, and the magnitude of effectively eroded volumes, but also the quantity of organic carbon released to the shallow Laptev Sea from coastal erosion, which ranged on a long-term from $88 \pm 21$ to $800 \pm 61 \mathrm{t}$ per km coastline per year and will correspond to considerably higher amounts, if recently observed more rapid coastal erosion rates prove to be persistent.

\section{Introduction}

Coastal erosion as a physical process along the marginal arctic shelf seas attracts increased attention not only in periglacial research and marine geosciences (e.g. Brown et al., 2003; Grigoriev and Rachold, 2003; Charkin et al., 2011; Vasiliev et al., 2011), but also in the public awareness in terms of rapid responses of coastal erosion due to climate warming, leading to landscape instability and increased hazard exposure (Forbes, 2011). Because of recently decreasing sea ice extent (Comiso et al., 2008; Maslanik et al., 2011), larger fetch (Asplin et al., 2012), wave action and storm activity (Jones et al., 2009a), a doubling in the duration of the open water season (Overeem et al., 2011), and rising air, permafrost, and sea water temperatures during the last decades (Romanovsky et al., 2010; Dmitrenko et al., 2011; AMAP, 2011), erosion of arctic permafrost coasts and land 


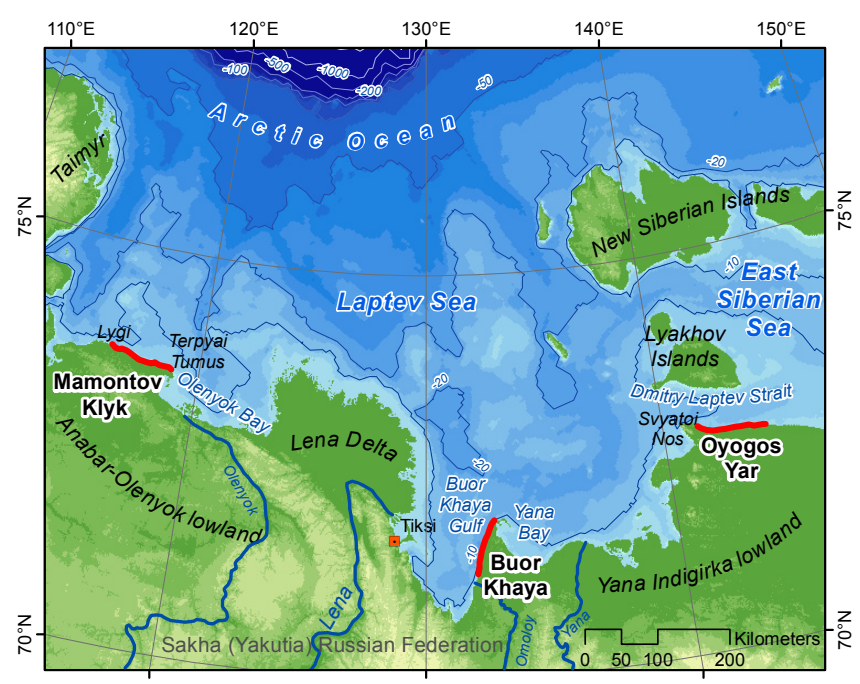

Fig. 1. Location of the study sites within the Laptev Sea region. Analyzed coastline sections are marked as red lines and comprise from west to east: Mamontov Klyk, Buor Khaya and Oyogos Yar.

loss are expected to increase. Increased material fluxes in the nearshore zone, including sediment, organic matter, and nutrients, affect marine ecosystems and primary production in arctic coastal habitats (Wassmann, 2011). The Arctic Ocean is the most land-dominated ocean basin, because of its large continental catchments (Peterson et al., 2002), where terrigeneous dissolved organic carbon is mobilized from high latitude carbon-rich soils and peatlands (Benner et al., 2004). Permafrost affected arctic coasts make up approximately $34 \%$ of the world's coastlines (Lantuit et al., 2011b), and feature a unique suite of coastal processes with strong seasonality, cold temperatures, permafrost, and sea ice, found nowhere else except Antarctica (Forbes, 2011). In the Laptev Sea region, $25 \%$ of the $7500 \mathrm{~km}$ long coastline is composed of very ice-rich permafrost deposits (Grigoriev et al., 2006), which are highly susceptible to erosion.

In many regions, the coastal zone of the shallow East Siberian Arctic Shelf has a dominantly heterotrophic character (Pipko et al., 2011), where organic and inorganic carbon from coastal erosion and river runoff result in sea acidification and out-gassing of $\mathrm{CO}_{2}$ to the atmosphere (Razumov and Grigoriev, 2011). In addition, Are (1999) and Rachold et al. (2000a) find that sediment release to the ocean from the coasts in the Laptev Sea region is at least of the same order of magnitude as the amount of riverine input, underlining the importance of coastal erosion processes and the need for better quantification.

Along permafrost-dominated coasts, heat transfer and melt of ground ice is added to the mechanical erosion forces of waves and ice. This process of thermo-erosion dominates the majority of the Laptev Sea coast (Fig. 1) and leads to rapid erosion rates and the subsequent inundation of continental polygenetic permafrost deposits (Winterfeld et al., 2011), in- cluding the ice complex (in Russian "ledovyi kompleks"; also called yedoma) and thermokarst (also called alas) deposits (e.g. Schirrmeister et al., 2011b). Geomorphologically, yedoma constitutes hilly uplands and alas low lying basins, establishing local differences in elevation, e.g. up to $27 \mathrm{~m}$ in the Lena Delta (Ulrich et al., 2010). Both types of deposits also contain high amounts of ground ice and soil organic carbon (Schirrmeister et al., 2011a; Strauss et al., 2012), making them generally very vulnerable to carbon mobilization from disturbances (e.g. Grosse et al., 2011), especially in coastal settings (Grigoriev et al., 2004; Semiletov et al., 2011).

Thermo-erosion creates coastal cliffs with geomorphological features unique to ice-rich coastlines. Two mass transport processes that combine thermal and mechanical forces to erode the coastline are thermo-denudation (TD) and thermoabrasion (TA) (see Are, 1978, 1988a,b; Dupeyrat et al., 2011, and Fig. 2). TA is defined as the combined mechanical and thermal effects of impinging wave energy at the shoreline. TD is defined as the combined influence of solar insolation and heat advection, influencing the energy balance at the ground surface above the water level, and can be conceived as periglacial coastal landslides. As an agent of TD, melt water from ground ice causes water saturation on coastal slopes, enabling gelifluction of blocks and mud stream development. In addition to erosion products resulting from TA, TD on coastal cliffs delivers eroded clastic material to the cliff's bottom edge and to the shore platform. Often, additional processes such as thermo-niche development and mechanical failure of ice-wedge polygonal blocks along eroding coasts enhance mass transport rates. We adopt the definition of thermo-erosion of the permafrost coast of Are (1988a) as the combined effects of TD and TA.

Ice Complex coasts have been studied by other researchers. For instance, Kaplina (1959) describes the acceleration of coastal erosion in connection with the occurence of large ice wedge bodies, leading to a reduction of material accruing during undercutting of coastal cliffs through thermo-niches. Klyuev (1970) carries out repeated surveys to quantify thermo-abrasion of the sea bottom. Are et al. (2005) developed a method for calculating coastal erosion rate based on the dimensions of thermo-terraces widespread across the Laptev Sea coast. Overduin et al. (2007) present a conceptual model of permafrost preservation under submarine conditions in dependence on coastal erosion rates. Grigoriev (2008) does monitoring and analytical work on coastal permafrost dynamics and mass fluxes on the East Siberian Arctic Shelf. Razumov (2010) systemizes endogenous and exogenous factors for modelling approaches of permafrost coastal erosion. Recent contributions are conducted by Pizhankova and Dobrynina (2010) and Lantuit et al. (2011a), who carry out remote sensing time series analyses of coastal erosion dynamics for the entire Lyakhov Islands and the Bykovsky Peninsula. 

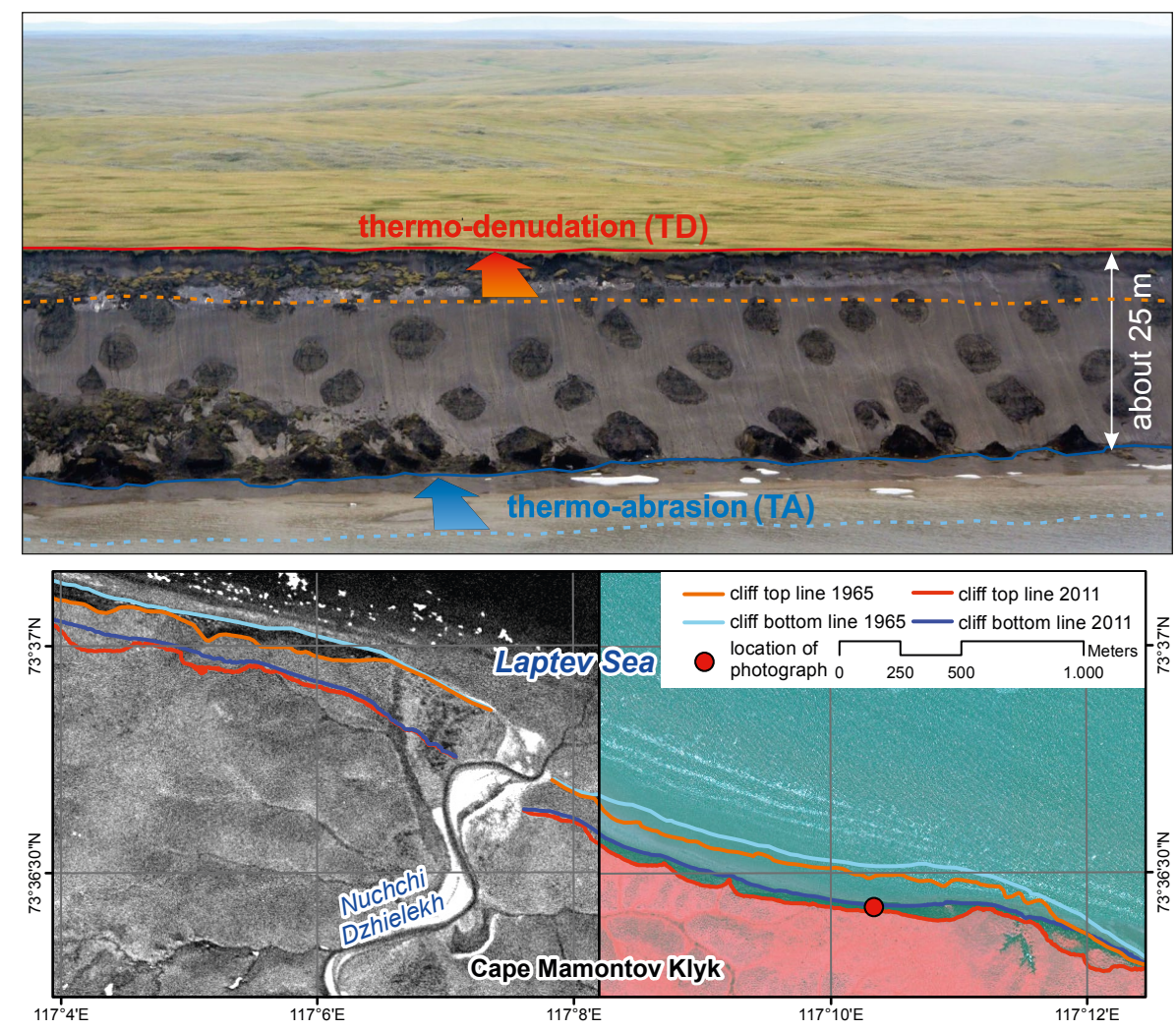

Fig. 2. Upper graphic: delineation of thermo-denudation (TD) and thermo-abrasion (TA) based on the example of a $25 \mathrm{~m}$ high yedoma coast composed of Ice Complex deposits in the western Laptev Sea between Cape Mamontov Klyk and Nuchchi Dzhielekh River mouth (photograph taken from helicopter, courtesy of H.-W. Hubberten); Lower graphic: the same section displayed with multi-temporal planimetric coastline positions in GIS (lower left: 1965 Corona KH-4A imagery as background; lower right: 2011 GeoEye imagery displayed as false colour infrared composite).

The Arctic Coastal Dynamics Project (Rachold et al., 2003; Lantuit et al., 2011b) report a weighted mean annual coastal erosion rate for the Laptev Sea of $-0.73 \mathrm{~m}$ per year $\left(\mathrm{ma}^{-1}\right)$. Grigoriev (2008) quantify a mean erosion rate of $-1.9 \mathrm{ma}^{-1}$, for coastal segments containing Ice Complex deposits. Usually, these values come from a variety of data sources, such as rare field surveys with high temporal frequency and comparison of historical aerial photographs with geodetic measurements (Grigoriev et al., 2003, 2009; Grigoriev, 2008). Studies on coastal erosion in the eastern sector of the Russian Arctic are spatially limited and inconsistent in their methods of data collection and interpretation. Therefore, satellite-based remote sensing offers the only viable mean of observing, quantifying and monitoring coastal erosion dynamics in the Arctic over large regions. Although the morphodynamics of permafrost coasts have been investigated in various regions, the relative intensities and contributions of TD and TA to erosion dynamics require detailed quantitative study. Despite the existence of absolute long-term and actual coastal erosion rates, adequate interpretation will depend on analyzing which processes drive local thermo-erosion.
The objective of this paper is to use observations of thermo-erosion along the Laptev Sea coastline to understand the relative contributions of TD and TA to the erosion of ice-rich permafrost coasts over the past four decades and over the past few years, in three different settings in the Laptev Sea region. We apply the concept of NormalizedDifference-Thermo-erosion-Index (NDTI) of Günther et al. (2012), as a dimensionless index of the ratio of TD and TA above the water level. Using state-of-the-art digital image processing and GIS change detection techniques, we determine and compare mean annual coastal erosion rates for long- and short-term observation periods. Using our findings, we discuss the impacts of these permafrost degradation processes on mass fluxes of organic carbon from land to arctic shelf sea. Understanding spatial patterns of thermo-erosion and how associated processes change over time will help us gain predictive capability as conditions for erosion in the Arctic are changing. 


\section{Study site description}

\subsection{Geographical setting}

All three study sites are located in northern Yakutia (Russian Federation) along the mainland coast of the Laptev Sea that extends from Taimyr in the west to Cape Svyatoi Nos at the transition to the East Siberian Sea (Fig. 1). Each site belongs to either the western, central or eastern sector of the Laptev Sea, as outlined by Rachold et al. (2000b). According to Treshnikov (1985), the territories of the outermost sites, Mamontov Klyk and Oyogos Yar, belong to the Arctic tundra and the Buor Khaya Peninsula to the northern tundra zone. The subarctic climate is continental and characterised by long harsh winters and short cold summers. Mean annual air temperature in Tiksi is $-11.5^{\circ} \mathrm{C}$ (Romanovsky et al., 2010), the amplitude of seasonal variation $40.6^{\circ} \mathrm{C}$ (Kholodov et al., 2012). Terrestrial permafrost is continuously distributed in the region (Popov, 1989). The Laptev Sea is one of the shallow Siberian shelf seas (Fig. 1) and is underlain by subsea permafrost, which is up to $500-650 \mathrm{~m}$ deep along the mainland coast (Romanovskii and Tumskoy, 2011). Roughly from October to June, the coastal sea is covered by thick one-year land fast sea ice. The sea ice-free season lasts for only $14 \%$ and $20 \%$ of the year in the western and in the eastern Laptev Sea, respectively (Dunaev and Nikiforov, 2001). The Olenyok-Anabar and Yana-Indigirka coastal lowlands (Fig. 1) represent former late Pleistocene accumulation plains. Subjected to permafrost degradation processes, nowadays their geomorphology is determined by levelling through thermokarst and drainage development directed toward the coast. By far the largest river in the region is the Lena River with an annual water discharge of $529 \mathrm{~km}^{3}$ (ROSHYDROMET and ArcticRIMS, 2009).

The Laptev Sea region is a unique geodynamic system, where active mid-oceanic seafloor spreading transforms into a passive rift system on continental crust (Sekretov, 2001), characterised by an alternating syncline-anticline system of neotectonic uplifted horsts and small grabens (Drachev et al., 1998). A variation of the coastal morphology in the Siberian Arctic is influenced by glacial isostatic adjustment during the Holocene (Whitehouse et al., 2007). West and Middle Siberian rivers terminate in estuaries, while East Siberian rivers form marine deltas. According to Whitehouse et al. (2007), the transition between these two types of drainages occur approximately at longitude $115^{\circ} \mathrm{E}$. This is the western starting point of our study site transect along the Laptev Sea mainland coast.

\subsection{Mamontov Klyk}

The studied coastline in the western Laptev Sea between the estuary of the Anabar River and the Olenyok River delta extends from Cape Lygi across Cape Mamontov Klyk to the former polar station at Cape Terpyai Tumus in the
East (Fig. 1; $73^{\circ} 41^{\prime} 45^{\prime \prime} \mathrm{N}, 115^{\circ} 53^{\prime} 7^{\prime \prime} \mathrm{E}$ and $73^{\circ} 33^{\prime} 11^{\prime \prime} \mathrm{N}$, $\left.118^{\circ} 42^{\prime} 16^{\prime \prime} \mathrm{E}\right)$. According to Schirrmeister et al. (2008) the stratigraphy of the permafrost sequences cropping out at the coast covers late Pleistocene and Holocene strata and is composed of less ice-rich fluvial silts and sands with peat layers, covered with 20-30 m thick ice-supersaturated silty to sandy Ice Complex deposits. Holocene thermokarst deposits have been found in alasses, thermoerosional valleys and in places discordantly superimposing the Ice Complex (Grosse et al., 2006). The hinterland of the coast is gently inclined towards the Laptev Sea in the north with a mean slope of $0.1^{\circ}$ and incised by a dendritic network of thermo-erosional valleys (Schirrmeister et al., 2008). Coastline length between the end points in this study near capes Lygi and Terpyai Tumus is $95 \mathrm{~km}, 56 \mathrm{~km}$ of which are studied. The remaining part of the coastline consists of river mouths with small deltaic accumulation cones, alluvial marshy bays, and marine terraces and sand spits, without visible erosion (e.g. Fig. 2). Although the coastline is generally straightened by thermo-abrasion, it features a wavy pattern with convex protrusions and concave indentations on a mesoscale of tens of kilometers. Klyuev (1970) describes alongshore coastal material drift from W to $\mathrm{E}$, resulting in the large sand accumulation zone at the outer margin of Terpyai Tumus. The high ground-ice volume renders this coastline exceptionally well suited for rapid cliff-top erosion rates.

\subsection{Buor Khaya}

The central study site is the western coast of the Buor Khaya Peninsula (Fig. 1). Bordered by two grabens that dissipated north of the Buor Khaya Cape (Imaeva et al., 2007), the peninsula is part of the Yana-Omoloi interfluve and an uplifted block. According to Strauss and Schirrmeister (2011), outcrops of Ice Complex and alas deposits consist of silty fine sand with peaty inclusions. The coast reveals a high heterogeneity of geomorphological units, such as tapped lake basins, alasses (9-14 $\mathrm{m}$ above mean sea level (a.m.s.l.)), yedoma hills (up to $37 \mathrm{~m}$ a.m.s.l.) and transition zones between the latter two. The hinterland is inclined towards the north with a mean slope of $0.05^{\circ}$, and is characterised by thermokarst relief. Isolated yedoma remnants cover only $15 \%$ of the area, which are dissipated by coalesced thermokarst basins. Dunaev and Nikiforov (2001) describe alongshore material drift from $\mathrm{S}$ to $\mathrm{N}$, manifested in the $30 \mathrm{~km}$ long Buor Khaya spit, the product of littoral processes. The length of the coast between the outermost points of this study $\left(71^{\circ} 20^{\prime} 41^{\prime \prime} \mathrm{N}, 132^{\circ} 3^{\prime} 23^{\prime \prime} \mathrm{E}\right.$ and $\left.71^{\circ} 56^{\prime} 49^{\prime \prime} 48\right) \mathrm{km}$ were studied.

\subsection{Oyogos Yar}

The third study region belongs to the Yana-Indigirka lowland and extends along the Oyogos Yar mainland coast of the Dmitry Laptev Strait from Cape Svyatoi Nos in the west 
to the Kondratyeva River mouth in the East (Fig. 1). Cape Svyatoi Nos is an isolated cretaceous granite dome (433 m a.m.s.l.), where the beach of the rocky coast is characterised by large sized boulders (Are et al., 2002). In the vincity of Svyatoi Nos, yedoma hills with Ice Complex remnants are degraded by closely spaced thermo-erosional valleys, become less frequent further east and are again found at the outer eastern margin of this segment. The stratigraphy at the Oyogos Yar coast includes Eemian lacustrine deposits followed by late Pleistocene Ice Complex deposits as well as Holocene thermokarst sequences (Wetterich et al., 2009). Most of the coast cuts through thermokarst depressions. According to Opel et al. (2011), alas bottoms reach elevations of about 8-12 m a.m.s.l. and consist of poorly sorted silt with peat inclusions and syngenetic ice wedges. The very gently inclined step-like landscape inland (Schirrmeister et al., $2011 \mathrm{~b}$ ) is drained by several thermo-erosional valleys. The direction of surface currents in the Dmitry Laptev Strait, the gateway to the East Siberian Sea, is towards the east. The coastline length (between $72^{\circ} 46^{\prime} 59^{\prime \prime} \mathrm{N} 141^{\circ} 30^{\prime} 51^{\prime \prime} \mathrm{E}$ and $72^{\circ} 39^{\prime} 20^{\prime \prime} \mathrm{N} 143^{\circ} 50^{\prime} 36^{\prime \prime} \mathrm{E}$ ) is $81 \mathrm{~km}$, all of which are included in this analysis.

\section{Methods}

\subsection{Remote sensing data fusion approach}

In order to provide a consistent picture of coastal erosion rates for our study sites, we applied a common best-practice strategy of data collection, fusion, examination and analysis to all three sites. Accurate monitoring of coastline changes using multi-temporal, multi-platform remotely sensed data requires consideration of various distortions, including distortions associated with the platform, the map projection, and shape of the earth's surface. In this study we use high and very high spatial resolution CORONA KH-4A and KH-4B, ALOS PRISM, KOMPSAT-2, SPOT-5, RapidEye and GeoEye optical space-borne imagery with differing geometric characteristics (Tables 1, 2, and 3). For coastline digitization we used images of similar high spatial resolution (0.5$2.5 \mathrm{~m}$ ). All images used were acquired at different times, and at different oblique viewing and azimuth angles.

Conventional 2-D polynomial rectification functions for image co-registration do not correct for relief induced and image acquisition system distortions. Toutin (2004) points out that 2-D ground control points (GCPs) correct for local distortions at the GCP location and are very sensitive to input errors. Consequently, this approach should be avoided for precise geometric multi-source/multi-format data integration. Our object of interest, the coastline, is always outside a cloud of GCPs on land. Therefore, the accuracy of our measurements rely heavily on correct terrain and sensor model approximation, since most images used are off nadir.

\subsection{Georeferencing and orthorectification}

Registration of multiple source imagery is one of the most important issues when dealing with remote sensing data (Le Moigne et al., 2011). Change detection over time requires multi-temporal data calibration through georeferencing, i.e. explicit assignment of geodata with absolute position information of a co-ordinate system. The initial georeferencing basis for GeoEye and RapidEye image data is a network of GPS GCPs of well-identifiable immobile features, such as small ponds, collected in the field. The GCPs which were incorporated into the tacheometric surveys are known with a high absolute accuracy of $\leq 1 \mathrm{~m}$. Other single GCPs were collected in the field using the GPS waypoint averaging function to achive good positional accuracy of 2$4 \mathrm{~m}$. Polygon ponds studied by Wetterich and Schirrmeister (2008), served as GCPs in the Oyogos Yar region. This selection of GCPs was then localized in the imagery and used for manual image registration. The potential georeferencing accuracy improves when ground resolution of the imagery increases. With the aid of additional parameter models as Fraser and Ravanbakhsh (2009) describe, georeferencing of GeoEye imagery (Geo \& GeoStereo level) showed very good results, often with sub-meter accuracy. For areas with no GeoEye coverage, RapidEye serves as a master data set for further registration purposes. Having RapidEye (Level 1B) wide area imagery that come with rational polynomial coefficients (RPC), we were able to filter out inaccurate GCPs and to establish for all sites a common and comparable high resolution reference data set with large areal coverage and absolute root mean square errors (RMSE $\delta_{\mathrm{a}}$ ) within pixel size (Tables 1, 2, and 3). It was used as a basis of equal quality for georeferencing all imagery for long-term observations, covering areas where no direct ground survey data were available. All data were projected using the respective UTM zone $(50 \mathrm{~N}, 53 \mathrm{~N}$ and $54 \mathrm{~N})$ on a WGS-84 model.

CORONA imagery may serve as a substitute for historic aerial imagery in northeast Siberia since it provides high ground resolution $(2-3 \mathrm{~m})$ and a historical record for observing long-term changes (Grosse et al., 2005). A challenging task is the rectification of panoramic CORONA KH-4A and $\mathrm{KH}-4 \mathrm{~B}$ imagery for mapping purposes. Sohn et al. (2004) describe several distortion overlap effects, which are maximized towards the ends of each photograph. Fragments of our sites lie at the margins of the film strips and are therefore strongly affected by perspective distortions. Following Pieczonka et al. (2011), we use Remote Sensing Graz (RSG, 2011) software for processing CORONA data of the years 1965, 1968, and 1969, which were obtained from the U.S. Geological Survey as four image tiles at $7 \mu \mathrm{m}$ scan resolution. Stitching image tiles and subsequent subsetting of a region of interest was done in Adobe ${ }^{\circledR}$ Photoshop ${ }^{\circledR}$ CS5.5, to retain the subset position within the full film strip dimensions. Using RSG with an implemented parametric sensor model, we were able to reconstruct the image acquisition 
Table 1. List of remote sensing data used for determination of thermo-erosion along the coast of Mamontov Klyk and corresponding characteristics.

\begin{tabular}{|c|c|c|c|c|c|}
\hline Sensor & $\begin{array}{l}\text { Date } \\
\text { dd.mm.yyyy }\end{array}$ & $\begin{array}{l}\text { Resolution }\left(\delta_{\mathrm{p}}\right) \\
(\mathrm{m})\end{array}$ & $\begin{array}{c}\operatorname{RMSE}\left(\delta_{\mathrm{a}} \& \delta_{\mathrm{r}}\right) \\
(\mathrm{m})\end{array}$ & $\begin{array}{l}\text { Orthorectification } \\
\text { basis }\end{array}$ & $\begin{array}{l}\text { Observation } \\
\text { period }\end{array}$ \\
\hline KH-4A AFT & 27.07.1965 & 2.9 & 2.05 & KH-4A DEM 1965 & long-term \\
\hline KH-4A AFT & 27.07.1965 & 2.7 & 2.9 & KH-4A DEM 1965 & long-term \\
\hline KH-4A AFT & 27.07.1965 & 2.5 & 4.42 & KH-4A DEM 1965 & long-term \\
\hline PRISM NDR & 22.07.2009 & 2.5 & 2.9 & PRISM DEM 2009 & long-term \\
\hline PRISM NDR & 05.10 .2009 & 2.5 & 2.65 & PRISM DEM 2009 & long-term \\
\hline PRISM WIDE & 12.10 .2007 & 2.5 & 2.07 & Topomap DEM* ${ }^{*}$ & long-term \\
\hline PRISM WIDE & 12.10 .2007 & 2.5 & 1.68 & PRISM DEM 2007 & short-term \\
\hline GeoEye-1 & 18.07.2009 & 0.5 & 0.47 & GeoEye DEM 2011 & short-term \\
\hline GeoEye-1 & 01.08 .2010 & 0.5 & 1.75 & PRISM DEM 2007 & short-term \\
\hline KOMPSAT-2 & 13.08 .2011 & 1.0 & 0.82 & PRISM DEM 2007 & short-term \\
\hline GeoEye-1 & 09.08 .2011 & 0.5 & 1.16 & GeoEye DEM 2011 & short- \& long-term \\
\hline GeoEye-1 & 09.08 .2011 & 0.5 & 1.05 & GeoEye DEM 2011 & short- \& long-term \\
\hline RapidEye & 29.07 .2011 & 6.5 & 3.18 & Topomap DEM* & master \\
\hline RapidEye & 09.08 .2011 & 6.5 & 3.93 & Topomap DEM* & master \\
\hline
\end{tabular}

Table 2. List of remote sensing and field data used for determination of thermo-erosion along the west coast of the Buor Khaya Peninsula and corresponding characteristics.

\begin{tabular}{llccll}
\hline Sensor & $\begin{array}{l}\text { Date } \\
\text { dd.mm.yyyy }\end{array}$ & $\begin{array}{c}\text { Resolution }\left(\delta_{\mathrm{p}}\right) \\
(\mathrm{m})\end{array}$ & $\begin{array}{c}\text { RMSE }\left(\delta_{\mathrm{a}} \& \delta_{\mathrm{r}}\right) \\
(\mathrm{m})\end{array}$ & $\begin{array}{l}\text { Orthorectification } \\
\text { basis }\end{array}$ & $\begin{array}{l}\text { Observation } \\
\text { period }\end{array}$ \\
\hline KH-4B AFT & 24.07 .1969 & 2.0 & 1.38 & Topomap DEM 1973 & long-term \\
KH-4B AFT & 24.07 .1969 & 2.0 & 1.94 & Topomap DEM 1973 & long-term \\
SPOT-5 HRV & 08.10 .2011 & 2.5 & 1.08 & SPOT-5 DEM 2012 & long-term \\
SPOT-5 HRV & 08.10 .2011 & 2.5 & 2.27 & SPOT-5 DEM 2012 & long-term \\
GeoEye-1 & 13.07 .2009 & 0.5 & 0.91 & SPOT-5 DEM 2012 & short-term \\
GeoEye-1 & 13.07 .2009 & 0.5 & 1.17 & SPOT-5 DEM 2012 & short-term \\
GeoEye-1 & 18.07 .2011 & 0.5 & 0.87 & GeoEye DEM 2011 & short-term \\
Geodetic survey & $05 .-17.08 .2010$ & - & $1.2-1.5$ & - & short-term \\
RapidEye & 08.082010 & 6.5 & 4.04 & Topomap DEM 1973 & master data set \\
\hline
\end{tabular}

geometry in order to calculate the effective ground resolution $\left(\delta_{\mathrm{p}}\right)$ in $\mathrm{m}$ of each CORONA subset from

$\delta_{\mathrm{p}}=\frac{h}{c_{\mathrm{k}}} \cdot \Delta \eta_{\mathrm{s}}$,

where $h$ is flight height $[\mathrm{m}], c_{\mathrm{k}}$ focal length $[\mu \mathrm{m}]$, and $\eta_{\mathrm{s}}$ digitizing distance $[\mu \mathrm{m}]$. Ground resolution ranged from 2.0-2.9 m (Tables 1, 2, and 3). We handled neighbouring and laterally overlapping scenes as joint photogrammetric image blocks for higher redundancy in the image model. We ortho-rectified CORONA data using digital elevation models (DEMs) created from CORONA along-track stereoscopic images acquired at the same time (Mamontov Klyk), from topographic maps with an contour equidistance of $10 \mathrm{~m}$ that were produced based on aerial surveys from 1973 (Buor Khaya), or from several ellipsoid-based ortho-image series using sea level or varying cliff heights as a basis (Oyogos Yar) with regard to coastal cliff-bottom and top-line delineation. For mapping purposes, the ortho- images of the CORONA AFT (backward looking) camera were preferred, as the FWD (forward looking) camera scenes showed either lower radiometric quality or less favourable overlap situation.

The Panchromatic Remote-Sensing Instrument for Stereo Mapping (PRISM) on board the Advanced Land Observing Satellite (ALOS) had a forward, backward, and nadir channel. They formed an along-track triplet scene with $2.5 \mathrm{~m}$ resolution. We corrected PRISM data (Level 1B1) from 2007 and 2009 for the Mamontov Klyk study site using DEMs that we generated from triplets (OBS1 data) and stereo scenes of backward and nadir looking scenes (OBS2 data). Prior to DEM extraction and orthorectification we reduced JPEG noise from PRISM data using the software of Kamiya (2008). Panchromatic data obtained by SPOT5-HRS (High Resolution Stereoscopic) also provided imagery at a comparable ground resolution of $2.5 \mathrm{~m}$. We corrected SPOT5 data (Level 1A) for Buor Khaya and Oyogos Yar using DEMs that we generated from 1-day interval across-track 
Table 3. List of remote sensing data used for determination of thermo-erosion along Oyogos Yar coast (Dmitry Laptev Strait) and corresponding characteristics.

\begin{tabular}{llccll}
\hline Sensor & $\begin{array}{l}\text { Date } \\
\text { dd.mm.yyyy }\end{array}$ & $\begin{array}{c}\text { Resolution }\left(\delta_{\mathrm{p}}\right) \\
(\mathrm{m})\end{array}$ & $\begin{array}{c}\text { RMSE }\left(\delta_{\mathrm{a}} \& \delta_{\mathrm{r}}\right) \\
(\mathrm{m})\end{array}$ & $\begin{array}{l}\text { Orthorectification } \\
\text { basis }\end{array}$ & $\begin{array}{l}\text { Observation } \\
\text { period }\end{array}$ \\
\hline KH-4A AFT & 26.06 .1968 & 2.9 & 3.57 & sea \& mean cliff-top level & long-term \\
KH-4A AFT & 26.06 .1968 & 2.7 & 4.78 & sea \& mean cliff-top level & $\begin{array}{l}\text { long-term } \\
\text { SPOT-5 HRV }\end{array}$ \\
09.10 .2011 & 2.5 & 2.87 & SPOT-5 DEM 2011 & long-term \\
KOMPSAT-2 & 25.09 .2009 & 1.0 & 1.01 & sea \& mean cliff-top level & short-term \\
KOMPSAT-2 & 04.08 .2011 & 1.0 & 2.94 & sea \& mean cliff-top level & short-term \\
RapidEye & 20.08 .2010 & 6.5 & 6.89 & Topomap DEM & master \& long-term \\
RapidEye & 26.08 .2010 & 6.5 & 3.51 & Topomap DEM & master \\
\hline
\end{tabular}

* Santoro and Strozzi (2012)

stereo pairs of the same data sets. In combination with the CORONA data sets, PRISM and SPOT-5 data span our longterm observation periods of several decades up to $43 \mathrm{yr}$.

To determine recent short-term coastal erosion rates, we used a time series of multiple GeoEye and KOMPSAT-2 very high resolution images. In case of a spatial overlap, these images were geo-referenced to each other, making it easier to find common GCPs close to the coastline. We applied pan-sharpening (Ehlers et al., 2010) to all KOMPSAT-2 and GeoEye-1 imagery, used for short-term measurements. All processing of recent remote sensing data was done using PCI Geomatic's ${ }^{\odot}$ Geomatica 2012 OrthoEngine.

\subsection{Field work}

Field sites were surveyed during joint Russian-German expeditions "Eastern Laptev Sea - Buor Khaya Peninsula 2010" (Wetterich et al., 2011) and "Western Laptev Sea - Mamontov Klyk 2011". During field work we produced a basic data set of precise topographic reference measurements for better interpretation of remote sensing products, to improve classification of coastal relief units and as input for the creation of large-area DEMs. Our geodetic measuring setup using a ZEISS ELTA C30 tacheometer and corresponding reflector mirrors is described in detail by Günther et al. (2011). A total of $6.7 \mathrm{~km}$ coastline distributed over six key sites was surveyed on Buor Khaya, and $2.1 \mathrm{~km}$ around Cape Mamontov Klyk. No measurements were made at Oyogos Yar. However, for this site we rely on existing literature about the Dmitry Laptev Strait region, which has been the subject of research on permafrost deposits (Wetterich et al., 2009), on the formation of subsea permafrost (Grigoriev, 2008), and coastal erosion (Pizhankova and Dobrynina, 2010).

\subsection{Coastline digitization}

Cliff-bottom and cliff-top coastlines were manually digitized separately using ESRI ${ }^{\circledR} \operatorname{ArcGIS}^{\mathrm{TM}} 10$ software. Delineating the same section of shoreline at different spatial scales results in different coastline lengths and therefore also different volumes for sediment flux (Lantuit et al., 2009). Depending on the complexity of the coastline and on-screen specific image contrast, we used fine mapping scales from $1: 500$ to 1 : 2000. Based on field observations, we notice erosion products are removed away without long residence on the cliff bottom. However, in some places mud flows accumulate in alluvial fans, blurring the cliff bottom and requiring consideration of the presence of failed material, which mostly still visually contrasts with the rugged coastal slope or brighter beach material. We used the Digital Shoreline Analysis System (DSAS) of Thieler et al. (2009), available as an extension to ArcGIS ${ }^{\mathrm{TM}}$, to calculate shoreline position changes between two dates; a method previously used, for example, for assessing coastal erosion on the Beaufort Sea coast (Jones et al., 2009a) as well as thermokarst lake shore erosion on the Seward Peninsula in Alaska (Jones et al., 2011). An arbitrary baseline located offshore and following the coastline was created by buffering the oldest seaward-most coastline, $100 \mathrm{~m}$ off the coast. Every $50 \mathrm{~m}$ along this baseline, transects perpendicular to the coastline were used for separate determination of cliff-bottom and cliff-top erosion, regarded as TA and TD, respectively (Fig. 2). Transects were classified as either yedoma hill or alas basin. Coastal erosion was measured as absolute displacement distance metrics over a known period of time. Therefore, coastal erosion rate was calculated using

$r=\frac{-1 \cdot\left(x_{1}-x_{2}\right)}{t_{1}-t_{2}}$,

where $x_{1}$ and $x_{2}$ are coastline positions relative to the baseline at times $t_{1}$ and $t_{2}$. The factor of -1 is used in order to define erosion as negative.

\subsection{Uncertainty assessment}

Uncertainty in planimetric coastline positions has numerous sources. To limit uncertainties, we work with a geometrically consistent data set of ortho-images. To quantify uncertainties we consider 
1. georeferencing to an absolute frame of a coordinate system $\left(\delta_{\mathrm{a}}\right)$,

2. relative georeferencing of two data sets to each other $\left(\delta_{\mathrm{r}}\right)$

3. the geometric resolution of the data set $\left(\delta_{\mathrm{p}}\right)$, and

4. relief-induced horizontal displacement as a result of orthorectification $\left(\delta_{\mathrm{Z}}\right)$.

The sources of uncertainty $\left(\delta_{\mathrm{a}}\right.$ and $\delta_{\mathrm{r}}$ ( depend on the method of image to image georeferencing. Data sets used for longterm measurements are referenced to a common reference data set, where the reference itself is not used for measurements. Here the georeferencing uncertainty is the geometric mean of the RMS errors $\delta_{\mathrm{r}}$ and $\delta_{\mathrm{a}}$ for each data set. For shortterm measurements we neglect $\delta_{\mathrm{a}}$ of the initial reference data set, because for relative coastline positions derived from second order derivates of data processing, the respective referencing basis provides itself a coastline position. That means, for data sets geo-referenced to each other, $\delta_{\mathrm{r}}$ is the RMS error of the mutual georeferencing. The uncertainty deriving from the spatial resolution of the data set is taken to be half of the spatial resolution. $\delta_{\mathrm{z}}$ arises out of a combination of errors in topographic approximation and the tilt angle associated with oblique image data acquisition, where both are unique to and are calculated from the underlying DEM data set. Relief-induced error is calculated from

$\delta_{\mathrm{z}}=\tan \alpha \cdot \Delta z$

where $\alpha$ is the tilt angle of the spacecraft and $\Delta z$ the vertical accuracy of the DEM. The cumulative uncertainty in coastline position for long-term measurements is then given by the quadratic sum:

$\delta x=\sqrt{\left(\sqrt{\delta_{\mathrm{a}}^{2} \cdot \delta_{\mathrm{r}}^{2}}\right)+\delta_{\mathrm{p}}^{2}+\delta_{\mathrm{z}}^{2}}$

and for short-term measurements accordingly by

$\delta x=\sqrt{\delta_{\mathrm{r}}^{2}+\delta_{\mathrm{p}}^{2}+\delta_{\mathrm{z}}^{2}}$.

The cumulative uncertainty in coastline position is given as $\delta x_{1}$ and $\delta x_{2}$ for positions at times $t_{1}$ and $t_{2}$, respectively. Uncertainties for acquisition times $(t)$ are less than $0.01 \%$ and are neglected. Assuming that the cumulative uncertainties in coastline position are random and independent, we calculate uncertainty in coastline position change rate as

$\delta r=\frac{\sqrt{\delta x_{1}^{2}+\delta x_{2}^{2}}}{t_{1}-t_{2}}$.

Uncertainties in change rate calculation may also arise from the discrepancy between taking the continuous time range or the duration of the factual sea ice free period. This effect applies especially for detection of short-term changes.

\subsection{Normalized Difference Thermo-erosion Index (NDTI)}

Since we aim at evaluating spatial patterns of thermoerosion, we did not quantify shore sections dominated by accumulation. Stable coasts included segments with extensive beaches and segments with inactive cliffs that did not change within our measurement uncertainties of a particular transect. Along segments where a cliff position was blurred, i.e. by undisturbed vegetation cover, we did not track cliff positions over time.

For ice-rich permafrost coasts, we assume that movement of the top of the coastal cliff is attributable to TD, and the movement of the cliff bottom is attributable to TA, as defined above (Fig. 2). Different relative intensities of these two processes create a large variety of coastal slope profiles (Sovershaev, 1992) and must be considered in measurements. Here, we apply the concept of the Normalized Difference Thermoerosion Index (NDTI) of Günther et al. (2012) that qualitatively describes the shape of coastal change and as a proxy allows for interpretation of planimetric erosion rates. NDTI is calculated from

$\mathrm{NDTI}=\frac{\text { thermodenudation }- \text { thermoabrasion }}{\text { thermodenudation }+ \text { thermoabrasion }}=\frac{\mathrm{TD}-\mathrm{TA}}{\mathrm{TD}+\mathrm{TA}}$

TD and TA values in the equation can be either absolute shoreline movement or rates over time. As a ratio of two numbers which have the same units, NDTI is a dimensionless quantity. NDTI values range from -1 (only TA) to +1 (only TD). Weaknesses of the NDTI approach are outlined in Günther et al. (2012) and mostly comprise the missing consideration of thermo-erosional niche development.

\section{Results}

\subsection{Coastal thermo-erosion at Mamontov Klyk}

Along the western study site coast, mean long-term TD and TA both were $-2.1 \mathrm{ma}^{-1}$ with a standard deviation of \pm 1.2 . The frequency of erosion rates between -0.5 and $-3.5 \mathrm{ma}^{-1}$ are nearly consistent (Fig. 3), except for very rapid rates $\left(\leq-3.5 \mathrm{ma}^{-1}\right)$. Differentiation of coastal erosion into TD and TA shows a bimodal distribution of all long-term TD and TA values, which reflects the spatial variability of thermoerosion along the whole coastline. Coastal erosional patterns along the Mamontov Klyk coast exhibit a break in WE direction (Fig. 4). From Cape Lygi in the west, to the Urasalakh River mouth, mean TD and TA were $-1 \mathrm{ma}^{-1}$, while coastline sections further east around capes Mamontov Klyk and Terpyai Tumus had TD and TA values around $-2.9 \mathrm{~m} \mathrm{a}^{-1}$ and $-2.5 \mathrm{ma}^{-1}$, respectively. Numerous regional sediment traps and non-eroding stable segments are interspersed among eroding segments of the Mamontov Klyk coast. The highest observed long-term TD rates on Mamontov Klyk yedoma coasts were about $-5.7 \mathrm{ma}^{-1}$, which was 


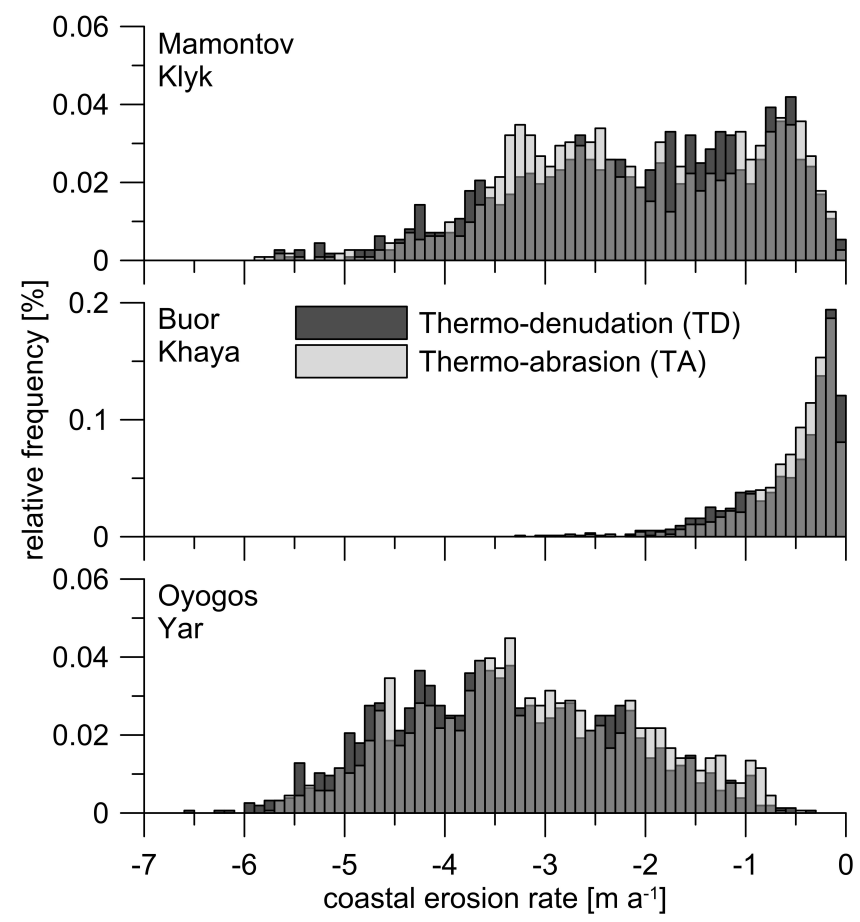

Fig. 3. Site specific histograms of long-term mean annual coastal erosion rates $\left(\mathrm{ma}^{-1}\right)$ obtained from coastal transect data, seperated into thermo-denudation (TD) and thermo-abrasion (TA) rates.

not necessarily connected with TA rates of the same order, while TD and TA rates for alas coasts were proportional to each other (Fig. 5). Measurements of TD and TA rates on Mamontov Klyk exhibit the strongest correlation $\left(r^{2}=0.68\right)$ for yedoma, when compared to Buor Khaya and Oyogos Yar. However, they lagged behind the high correlation of TD and TA along alas $\left(r^{2}=0.95\right)$. On the Mamontov Klyk coast, we observed the least variation in erosion rates between different coastline types, where TD and TA rates for alas are in the range of only 10-15\% lower than for yedoma transects. NDTI data revealed long-term values of 0.14 and -0.12 for TD and TA dominated coasts, respectively. Figure 6 shows an equal distribution of NDTI for the Mamontov Klyk coast, where TA is observed slightly more frequently.

The temporal variability is reflected in a recently more rapid mean TD $\left(-4.5 \mathrm{ma}^{-1} \pm 1.2\right)$ and mean TA short-term rates $\left(-4.6 \mathrm{ma}^{-1} \pm 1.2\right)$, compared to long-term observations of $-2.8 \mathrm{ma}^{-1}$ and $-2.9 \mathrm{ma}^{-1}$, respectively (Fig. 7). Most outliers $\left(\geq-21 \mathrm{ma}^{-1}\right)$ are to more rapid erosion events (rather than slower) of TD in short-term measurements at capes Mamontov Klyk and Terpyai Tumus. Short-term NDTI values have a broader spectrum of \pm 0.23 compared to longterm spectrum of \pm 0.14 (Fig. 6), but neither show a shift towards TD nor TA.

\subsection{Coastal thermo-erosion at Buor Khaya}

Long-term coastal erosion along the west coast of the Buor Khaya Peninsula is $-0.55 \mathrm{ma}^{-1}( \pm 0.5)$ for TD and $-0.5 \mathrm{ma}^{-1}( \pm 0.4)$ for TA. Distributions of both were skewed towards small erosion rates (Fig. 3). At site-specific more rapid erosion rates $\left(\leq-1 \mathrm{ma}^{-1}\right)$, as well as at very slow rates, TD is observed more often than TA. On Buor Khaya, long-term thermo-erosion was spatially highly variable along the coastline (Fig. 8). A thermokarst lagoon at $71^{\circ} 47^{\prime} \mathrm{N}$ forms the centre of a weakly pronounced elongated concave coastline section where no erosional activity was observed. Our results indicate that, north of the thermokarst lagoon the coast is influenced by prevailing TA, while TD is the dominant process north and south of the Orto-Stan River mouth at $71^{\circ} 34^{\prime} \mathrm{N}$. However, the largest contrasts in erosional patterns are not observed on a regional scale, but rather associated with variations in coastal geomorphology. Based on the classification of transects, alas lagged behind yedoma coasts with $-0.3 \mathrm{ma}^{-1}$ compared to $-1 \mathrm{ma}^{-1}$ for TD, and $-0.4 \mathrm{ma}^{-1}$ compared to $-0.7 \mathrm{ma}^{-1}$ for TA. Figure 5 shows clustering of long-term TD and TA values at a low level, with some exceptions of high TD in conjunction with high TA rates, but for yedoma coasts. Coherence of TD and TA for alas coasts $\left(r^{2}=0.82\right)$ at Buor Khaya is lowest of the three sites, and in particular for yedoma coasts this correlation is only weak $\left(r^{2}=0.39\right)$. NDTI varied widely from -0.25 to 0.95 (Fig. 6), suggesting that, in contrast to the other sites, TD has dominated over the long-term at Buor Khaya.

During the short-term period, a major shift of TD and its associated variability to more rapid erosion rates $\left(-7.7 \mathrm{ma}^{-1} \pm 4.4\right)$ was observed (Fig. 7). However TA rates were more rapid as well, but remained slower $\left(-1.2 \mathrm{ma}^{-1} \pm 0.7\right)$. Consequently, short-term NDTI is highly skewed to positive values, indicating that TD has dominated at an even higher intensity here over the past few years, compared to the long-term mean (Fig. 6).

\subsection{Coastal thermo-erosion at Oyogos Yar}

The entire Oyogos Yar coast has been continuously eroding at mean long-term TD and TA rates of $-3.4 \mathrm{ma}^{-1}( \pm 1.1)$ and $-3.2 \mathrm{ma}^{-1}( \pm 1.1)$, respectively. Figure 3 shows TD and TA equally centred around these mean rates with a wide distribution. At slower rates, TA is observed more frequently, while at more rapid than mean rates TD prevailed. There were a few transects at yedoma coasts east of the Kondratyeva River mouth, where rates of $\leq-6.5 \mathrm{ma}^{-1}$ were observed as the most rapid long-term cliff-top erosion rate across all three study sites. In general, the spatial pattern could be characterised as a constant increase in eastern direction of TD and TA from the west towards the middle of the study site, and then a slight decrease towards the eastern end (Fig. 9). In contrast to the other study sites, TD values along alas coasts of Oyogos Yar were somewhat more rapid 


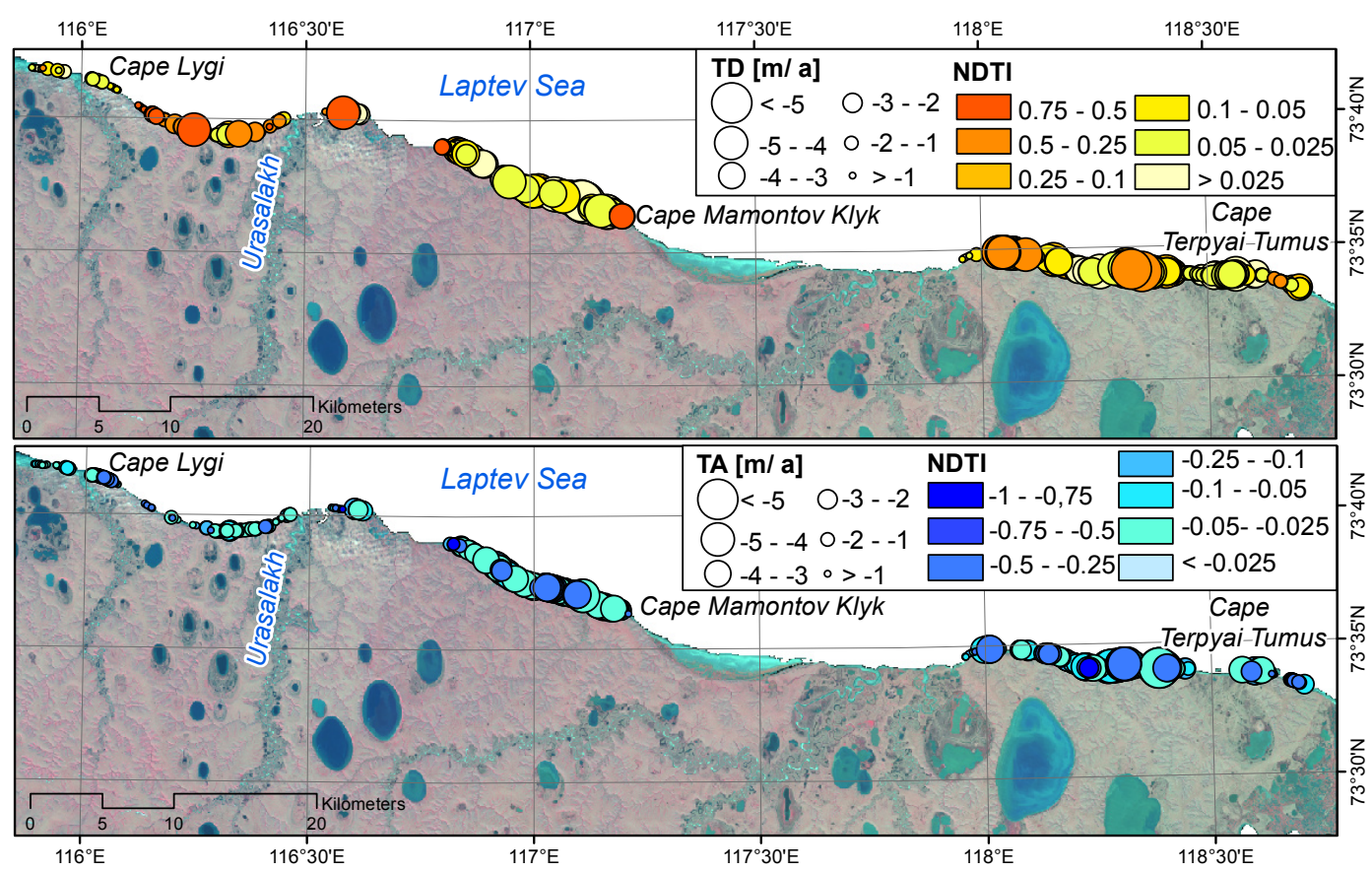

Fig. 4. Thematic map of coastal thermo-erosion transect data along the studied coastline of Mamontov Klyk (Anabar-Olenyok lowland). The upper map segment illustrates colour coded positive NDTI values associated with prevailing thermo-denudation (TD), the lower map illustrates colour coded negative NDTI values associated with prevailing thermo-abrasion (TA). The symbol size is equivalent to erosion values.
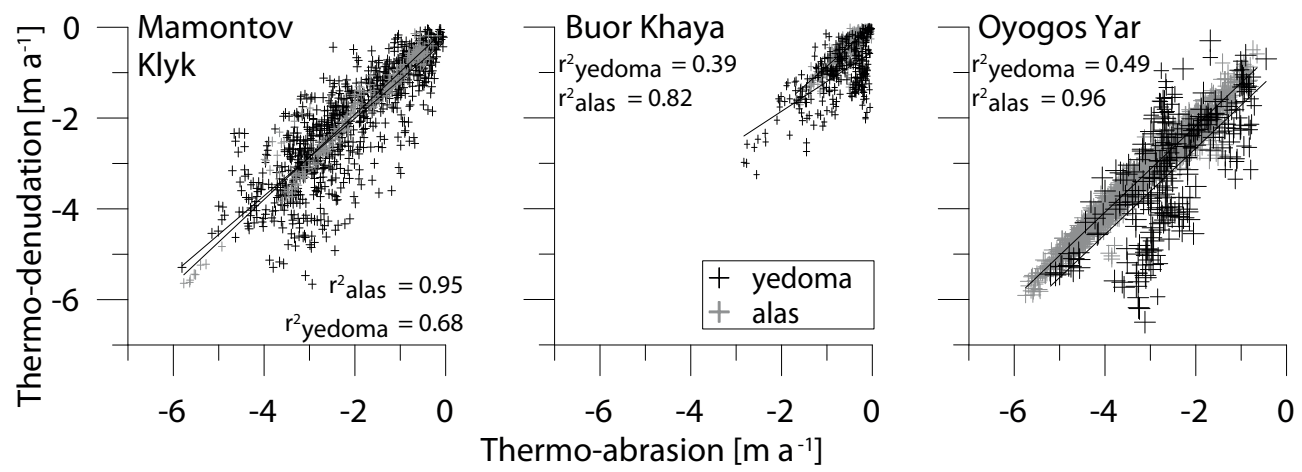

Fig. 5. Mean annual thermo-denudation (TD) vs. thermo-abrasion (TA) rates, divided into alas and yedoma coastline types by study sites. Cross symbols are built of error bars of TD and TA rate uncertainty (see Sect. 3.5), corresponding to the TD and TA axis, respectively.

than those for yedoma $\left(-3.4\right.$ compared to $\left.-3.2 \mathrm{ma}^{-1}\right)$, while TA $\left(-3.3 \mathrm{~m} \mathrm{a}^{-1}\right.$ for alas) was more rapid than long-term erosion rates along yedoma coasts $\left(-2.5 \mathrm{ma}^{-1}\right)$. Figure 5 shows that TD and TA along alas coasts had a linear relationship $\left(r^{2}=0.96\right)$, while thermo-erosion of yedoma along Oyogos Yar takes a medium position of all three study sites, resulting in a weak coupling of TD and TA $\left(r^{2}=0.49\right)$. NDTI values are densely centred around 0 , with a narrow frequency distribution (Fig. 6). This is consistent with low mean NDTI values of 0.06 and -0.04 , for TD- and TA-dominated coastal transects, respectively. However, long-term TD outpaced TA along $80 \%$ of all yedoma transects, which is also reflected in a positive NDTI of 0.18 .

In contrast, there is a negative shift in short-term NDTI relative to long-term NDTI, with values spread over a broader value domain. In the recent past, TA has dominated TD at $75 \%$ of the short-term transects with a mean short-term NDTI at Oyogos Yar of -0.27 (Fig. 6). In fact, both shortterm erosion rates are more rapid with mean TD rates of $-6.2 \mathrm{ma}^{-1}( \pm 2.7)$ and $-8.3 \mathrm{ma}^{-1}( \pm 2.8)$ for TA (Fig. 7). 


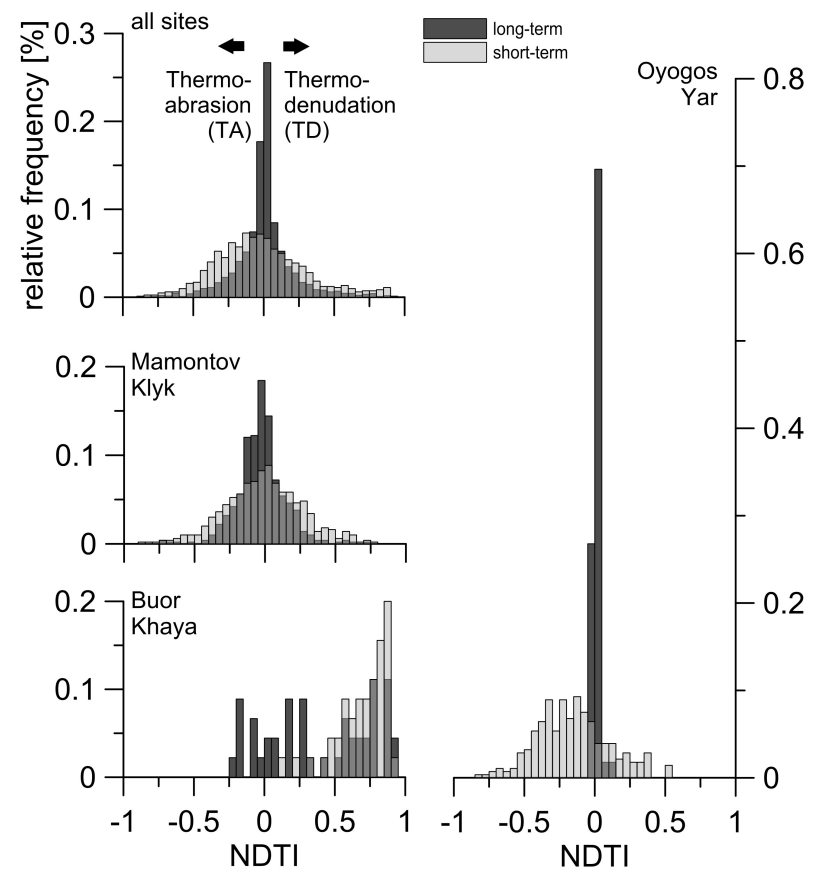

Fig. 6. Histograms of Normalized Difference Thermo-erosion Index (NDTI) values for the two time periods of observation are shown (from top to bottom) for the three coastal study sites considered as a whole and separately for Mamontov Klyk, Buor Khaya, and Oyogos Yar. Negative NDTI values indicate prevailing thermo-abrasion (TA), positive NDTI values thermo-denudation (TD).

\subsection{Coastal thermo-erosion in the Laptev Sea region}

A total of 3635 transects along $182 \mathrm{~km}$ of coastline were analyzed and quantified on a long-term scale of 39 to $43 \mathrm{yr}$. Over a mean interval of $42 \mathrm{yr}$ across the long-term study over all three sites, mean absolute TD was $93.3 \mathrm{~m}( \pm 65)$, while mean absolute TA was $89.3 \mathrm{~m}( \pm 63.1)$. This equals a mean TD rate of $-2.2 \mathrm{ma}^{-1}( \pm 1.6)$ and a mean TA rate of $-2.1 \mathrm{ma}^{-1}( \pm 1.5)$. Uncertainties were about $\delta_{\mathrm{r}} \pm 0.14 \mathrm{ma}^{-1}$ for TD and $\delta_{\mathrm{r}} \pm 0.12 \mathrm{ma}^{-1}$ for TA. For most transects and nearly at all intensities, TD and TA were proportional to one another (Fig. 3). The majority of outliers were due to TD rates exceeding TA. We found that mean long-term TD rates, as well as their variation, were nearly identical to TA rates for each site, when considered as a whole, although maps of thermo-erosion reveal spatially highly variable erosion (Figs. 4, 8, and 9). Long-term NDTI data show mean values of 0.12 and -0.13 for coastlines tending to erode (based on our sampling) under either prevailing TD or TA, respectively. TD exceeded TA at $55 \%$ of all transects and TA outpaced TD at $45 \%$, suggesting a slightly thermo-denudational coastal erosion regime. Figure 6 shows the skewed distribution of negative and positive NDTI values towards equilibrium of TD and TA. Figure 5 demonstrates that TD along alas coasts was directly linked to TA, while thermo-erosion on yedoma cliffs showed greater variability, as evident from
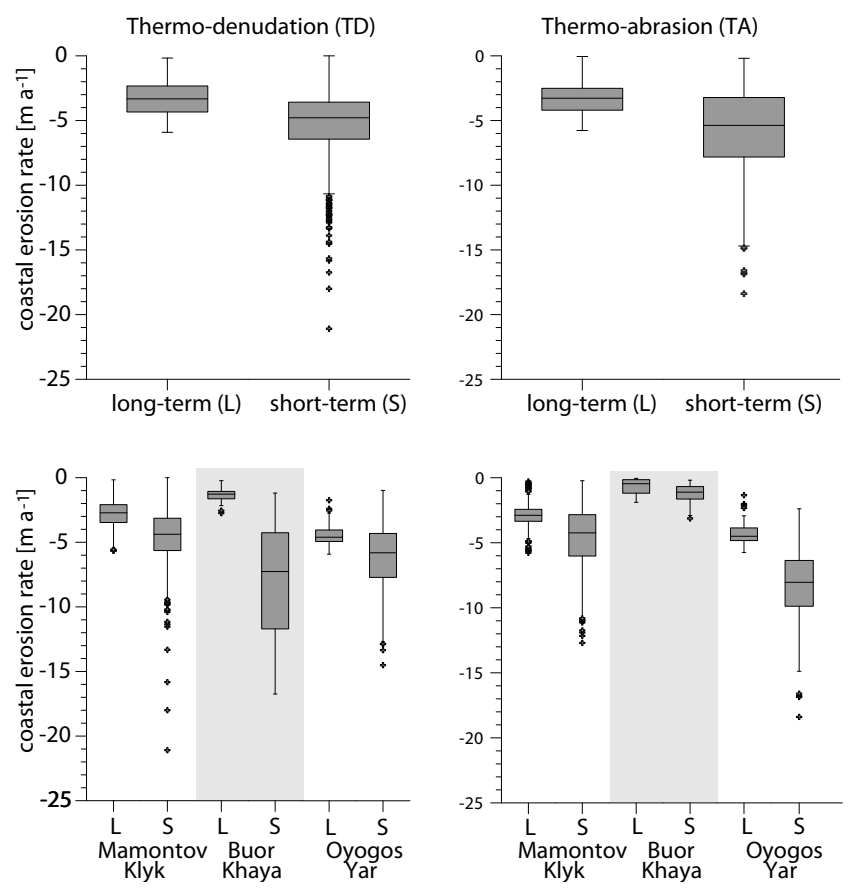

Fig. 7. Box plots of the thermo-erosion rates for long-term (39 to $43 \mathrm{yr}$ ) and short-term measurements (last 1 to $4 \mathrm{yr}$ ). Upper graphs: distribution of all TD (upper left) and TA (upper right) measurements $(n=3635)$, for long- and short-term periods. Lower graphs: distribution of off all thermo-denudation (TD; lower left) and thermo-abrasion (TA, lower right) measurements from transects, for which both long- and short-term observations are available, plotted separately by study sites Mamontov Klyk, Buor Khaya, and Oyogos Yar. Box plots show lower and upper quartiles, medians and outliers (points), defined as erosion rates more than 1.5 times the interquartile range above or below the median.

associated correlation coefficients between TA and TD of $r^{2}=0.82$ (yedoma) and $r^{2}=0.99$ (alas), when analyzed across all three sites.

Recent erosion rates over the past mean $2 \mathrm{yr}$ were determined at 824 of the 3635 coastal transects and are at least 1.6 times higher than over the $42 \mathrm{yr}$ long-term mean. Although there are differences in the long- and short-term transect proportion between the three sites, we assume that the $23 \%$ sample is sufficient to establish that recent TA was 2.4 times and recent TD 3.0 times more rapid than long-term means. Short-term erosion rates, whether the top or the bottom of the cliffs are used as the coastline, were more rapid $(-5.3$ to $-5.7 \mathrm{ma}^{-1}$ for short-term vs. -2.1 to $-2.2 \mathrm{ma}^{-1}$ for long-term) and have a greater variation $\left(-2.8\right.$ to $-3.2 \mathrm{ma}^{-1}$ vs. -1.5 to $-1.6 \mathrm{~m} \mathrm{a}^{-1}$ for long-term) than long-term rates. This is true for each site and for all three sites considered as a group (Fig. 7). 
Table 4. Total organic carbon (TOC) flux that result from the erosion observed in the Laptev Sea region. Values are separated by site (Mamontov Klyk, Buor Khaya, Oyogos Yar) and, within each site, by yedoma and thermokarst depression (alas).

\begin{tabular}{|c|c|c|c|c|c|c|}
\hline & \multicolumn{2}{|c|}{ Mamontov Klyk } & \multicolumn{2}{|c|}{ Buor Khaya } & \multicolumn{2}{|c|}{ Oyogos Yar } \\
\hline & yedoma & alas & yedoma & alas & yedoma & alas \\
\hline$N$ of transects & 880 & 241 & 293 & 660 & 272 & 1289 \\
\hline erosion $(\mathrm{TD}+\mathrm{TA})\left(\mathrm{ma}^{-1}\right)$ & -2.13 & -1.84 & -0.85 & -0.38 & -2.85 & -3.38 \\
\hline mean cliff height (m) & 16.5 & 4 & 22.5 & 10.5 & 23 & 10 \\
\hline eroded volume $\left(\mathrm{m}^{3}\right)$ & $1.54 \times 10^{6}$ & $0.09 \times 10^{6}$ & $0.28 \times 10^{6}$ & $0.13 \times 10^{6}$ & $0.89 \times 10^{6}$ & $2.18 \times 10^{6}$ \\
\hline uncertainty $\left(\mathrm{m}^{3}\right)$ & $\pm 9 \times 10^{3}$ & $\pm 1 \times 10^{3}$ & $\pm 4 \times 10^{3}$ & $\pm 6 \times 10^{3}$ & $\pm 12^{3}$ & $\pm 23 \times 10^{3}$ \\
\hline mean TOC $\left(\mathrm{kg} \mathrm{m}^{-3}\right)$ & $21.8^{\mathrm{a}}$ & $23.1^{\mathrm{a}}$ & $13.4^{\mathrm{b}}$ & $19.9^{\mathrm{b}}$ & $17.6^{\mathrm{a}}$ & $28.1^{\mathrm{a}}$ \\
\hline Std. Dev. $(n)$ & $\pm 9.1(31)^{\mathrm{a}}$ & $\pm 7.2(4)^{\mathrm{a}}$ & $\pm 11.0(47)^{\mathrm{b}}$ & $\pm 9.6(34)^{b}$ & $\pm 13.3(18)^{\mathrm{a}}$ & $\pm 6.3(5)^{\mathrm{a}}$ \\
\hline estimated ice wedge vol. (\%) & $50^{\mathrm{a}}$ & $10^{\mathrm{a}}$ & $50^{\mathrm{b}}$ & $10^{\mathrm{b}}$ & $50^{\mathrm{a}}$ & $10^{\mathrm{a}}$ \\
\hline corrected TOC $\left(\mathrm{kg} \mathrm{m}^{-3}\right)^{\mathrm{c}}$ & 10.92 & 20.81 & 6.73 & 17.91 & 8.79 & 25.25 \\
\hline uncertainty $\left(\mathrm{kg} \mathrm{m}^{-3}\right)^{\mathrm{c}}$ & 4.5 & 6.5 & 5.5 & 8.6 & 6.7 & 5.7 \\
\hline total annual carbon flux (t) & $16 \times 10^{3}$ & $1.8 \times 10^{3}$ & $1.9 \times 10^{3}$ & $2.3 \times 10^{3}$ & $7.8 \times 10^{3}$ & $55 \times 10^{3}$ \\
\hline uncertainty (t) & $\pm 8 \times 10^{3}$ & $\pm 0.1 \times 10^{3}$ & $\pm 1.7 \times 10^{3}$ & $\pm 1.3 \times 10^{3}$ & $\pm 6.8 \times 10^{3}$ & $\pm 17 \times 10^{3}$ \\
\hline annual flux & 380 & 150 & 130 & 70 & 570 & 850 \\
\hline per $\mathrm{km}$ coastline $\left(\mathrm{tkm}^{-1}\right)$ & & 330 & & 88 & & 800 \\
\hline
\end{tabular}

a Schirrmeister et al. (2011b);

b unpublished data, Strauss (2013);

c calculated following Strauss et al. (2012).

\subsection{Carbon mass fluxes}

Ice Complex deposits contain a significant carbon pool (Schirrmeister et al., 2011a). Strauss et al. (2012) calculate the volumetric carbon content of Ice Complex deposits by combining measured total organic carbon (TOC) with bulk density values. The bulk density of ice complex sequences varies primarily due to ground-ice content rather than TOC content (Strauss et al., 2012). Segregated gravimetric ground-ice content on Buor Khaya is on average $93 \%$ and $48 \%$ by weight for Ice Complex and alas deposits, respectively (Strauss and Schirrmeister, 2011). Ice Complex deposits on Mamontov Klyk are generally icesupersaturated, with $160-220 \%$ by weight (Schirrmeister et al., 2008). According to Schirrmeister et al. (2011b), ice complex sediments at Oyogos Yar are ice supersaturated with ice contents up to $200 \mathrm{wt} \%$. For the results shown in Table 4 , we use volumetric ice contents of $10 \%$ for thermokarst deposits in alas basins and 50\% for Ice Complex deposits constituting yedoma hills, and site specific organic carbon contents measured on coastal outcrops, based on J. Strauss (personal communication, 2013) and Schirrmeister et al. (2011b). Combining long-term mean annual coastal erosion rates with mean cliff height (based on DEMs) for each study site, we used an 2.5-D approach to determine annual eroded volumes $\left[\mathrm{m}^{3}\right]$ as

$V=\frac{1}{2}(\mathrm{TD}+\mathrm{TA}) \cdot h \cdot 50 \cdot n$,

where TD and TA are annual rates of cliff-top and cliffbottom erosion rates in $\left(\mathrm{ma}^{-1}\right), h$ is mean cliff height in $(\mathrm{m})$,
50 the coastline length covered by one coastal transect in (m), and $n$ the number of coastal transects. Table 4 shows values used to calculate carbon flux rates that result from the erosion observed in this study.

We obtained a total annual carbon flux, based on a volume of eroded material of $5.1 \times 10^{6} \pm 0.1 \times 10^{6} \mathrm{~m}^{3}$, of $85.6 \times 10^{3} \pm$ $0.7 \times 10^{3} \mathrm{t}$ for a total coastline length of $182 \mathrm{~km} .28 \%$ of this total originates from the erosion of yedoma, and $72 \%$ from alas coasts, although $50 \%$ of the eroded volume is derived from yedoma coasts. Higher TOC contents and lower ice volumes explain the higher carbon flux from alas coasts. The mean annual land-to-sea carbon flux therefore is $471 \pm 32.9 \mathrm{t}$ per $\mathrm{km}$ of coastline per year. Current estimate of Laptev Sea coastline length is $7500 \mathrm{~km}$ (Grigoriev et al., 2006). Grigoriev (2008) estimates $25 \%$ of the Laptev Sea coast to belong to Ice Complex deposits, including alas. Based on our observations, we found that only $74 \%$ of the studied Ice Complex coasts are actually eroding. Assuming this fraction to be representative, eroding Ice Complex coasts are then $1400 \mathrm{~km}$ long. As a result, total annual carbon flux released from eroding Ice Complex coasts is about $0.66 \times 10^{6} \pm 0.05 \mathrm{t}$.

\section{Discussion}

\subsection{Spatial variations of coastal thermo-erosion rates}

One source of the heterogeneity of spatial coastal erosional patterns of our sites is the variable thermokarst relief that advancing erosion encounters (Romanovskii et al., 2000). Grouping of our transects into yedoma (hills) and alas 


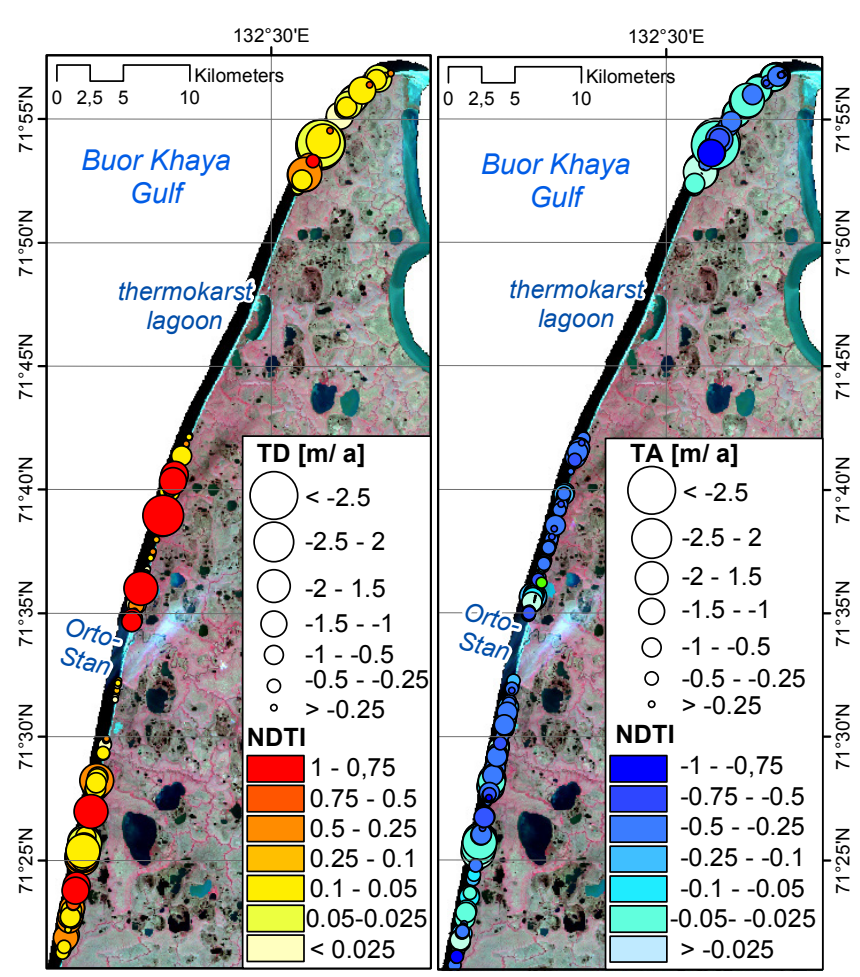

Fig. 8. Thematic map of coastal thermo-erosion transect data along the studied coastline of Buor Khaya (west coast of the Buor Khaya Peninsula). The upper map segment illustrates colour coded positive NDTI values associated with prevailing thermo-denudation (TD), the lower map illustrates colour coded negative NDTI values associated with prevailing thermo-abrasion (TA). The symbol size is equivalent to erosion values.

(basins) shows different extents of permafrost degradation between sites along the coast and may help to explain this spatial heterogeneity. While yedoma segments along the Mamontov Klyk coast made up $78 \%$ of the coastline, this value was $31 \%$ at Buor Khaya, and along the Dmitry Laptev Strait mainland coast only $17 \%$. Although this estimation does not include unstudied intervening sections, the proportions are generally of this magnitude. Intra-site specific erosion rates varied between yedoma and alas coasts, but unexpectedly this was not pronounced across the study site transect, with an increased proportion of permafrost degradation landforms from $\mathrm{W}$ to $\mathrm{E}$, mainly because of the comparatively slow rates on Buor Khaya.

Erosion rates along the Mamontov Klyk coastline from Cape Lygi to the Urasalakh River mouth are much slower than around the capes Mamontov Klyk and Terpyai Tumus. External factors such as the proximity of Terpyai Tumus and Mamontov Klyk to the warm waters of the Olenyok river may account for this difference. In contrast, Lantuit et al. (2011a) find relatively slow mean coastal erosion rates of $-0.6 \mathrm{ma}^{-1}$ on the Bykovsky Peninsula, which is directly exposed to the Lena River. Compared to the simple and straight outline of the other sites, the Mamontov Klyk coast features coastal promontories alternating with large half-rounded inland embayments between capes that probably align with former thermokarst lagoons. TA between Cape Lygi and the Urasalakh River mouth is therefore less intensive because of the sheltered sector along a concave coastline. Rapid coastal erosion rates $\left(-3.4 \mathrm{ma}^{-1}\right)$ around Cape Mamontov Klyk formed a steep $25 \mathrm{~m}$ high cliff, exposing homogeneous Ice Complex deposits across the whole profile (see photograph, Fig. 2). However, near the navigation mark on Cape Mamontov Klyk, where the backshore elevation is $33 \mathrm{~m}$, Ice Complex deposits are underlain by sands with low ground-ice content up to $10 \mathrm{~m}$ a.s.l. (Schirrmeister et al., 2008). Here, mean long-term TA is only $-1 \mathrm{ma}^{-1}$ and TD $-2 \mathrm{ma}^{-1}$, suggesting that poorly stratified coastal cliffs exhibit more complex erosional patterns, where upper ice-rich parts may recede faster, forming thermo-terraces, often on geological unconformities (Are et al., 2005).

Along the whole Buor Khaya coast north of the Omoloy River mouth, large sandy beaches (up to $2.5 \mathrm{~m}$ a.s.l. high and $50 \mathrm{~m}$ wide), containing allochtonous gravel, protect the shore face from the development of thermo-erosional niches. Unlike the other two sites, the Buor Khaya coast is west facing and hence particularly affected by prevailing westerly winds, so that swash dominates over backwash, resulting in positive budgets of beach material. Slope debris at the cliff bottom along the entire coast illustrates the episodic character of coastal thermo-erosion on Buor Khaya, where simultaneous reworking of products from TD through TA is hampered by beach morphology. Driftwood is present along much of the beach, reflecting proximity to the Lena River (Hellmann et al., 2013), but also the role of high water events in depositing material high on the beach. Based on our field observations, we agree with Are (2012), who finds that the bright colour of the beach material south of the thermokarst lagoon (Fig. 8) is very dissimilar to the dark greyish sediment of the adjacent Ice Complex, while north of the thermokarst lagoon, beach material is similar to the outropping Ice Complex. Furthermore, single baydzherakhs (thermokarst mounds from thawing Ice Complex) have been found in the field at sea level. Probably the lower Ice Complex boundary can be found here below sea level, favoring TA through a higher subsidence potential of the shore platform when thawing occurs, with subsequential increase and maintenance of higher wave energy when it is not compensated by sediment accumulation. Günther et al. (2011) report a two times steeper shoreface profile across the northern coast section compared to another study site $50 \mathrm{~km}$ southwards. Shallow coastal waters in the southern part of the Buor Khaya Gulf lower wave energy at the beach, hampering abrasive material removal from the cliff bottoms. Therefore, the spatial erosional pattern on Buor Khaya can be described as a TA-dominated north and a TD-dominated south, divided by a thermokarst lagoon, exhibiting a gently concave shaped inland coastline. Are et al. (2000) report cliff-top (TD) erosion rates on two 

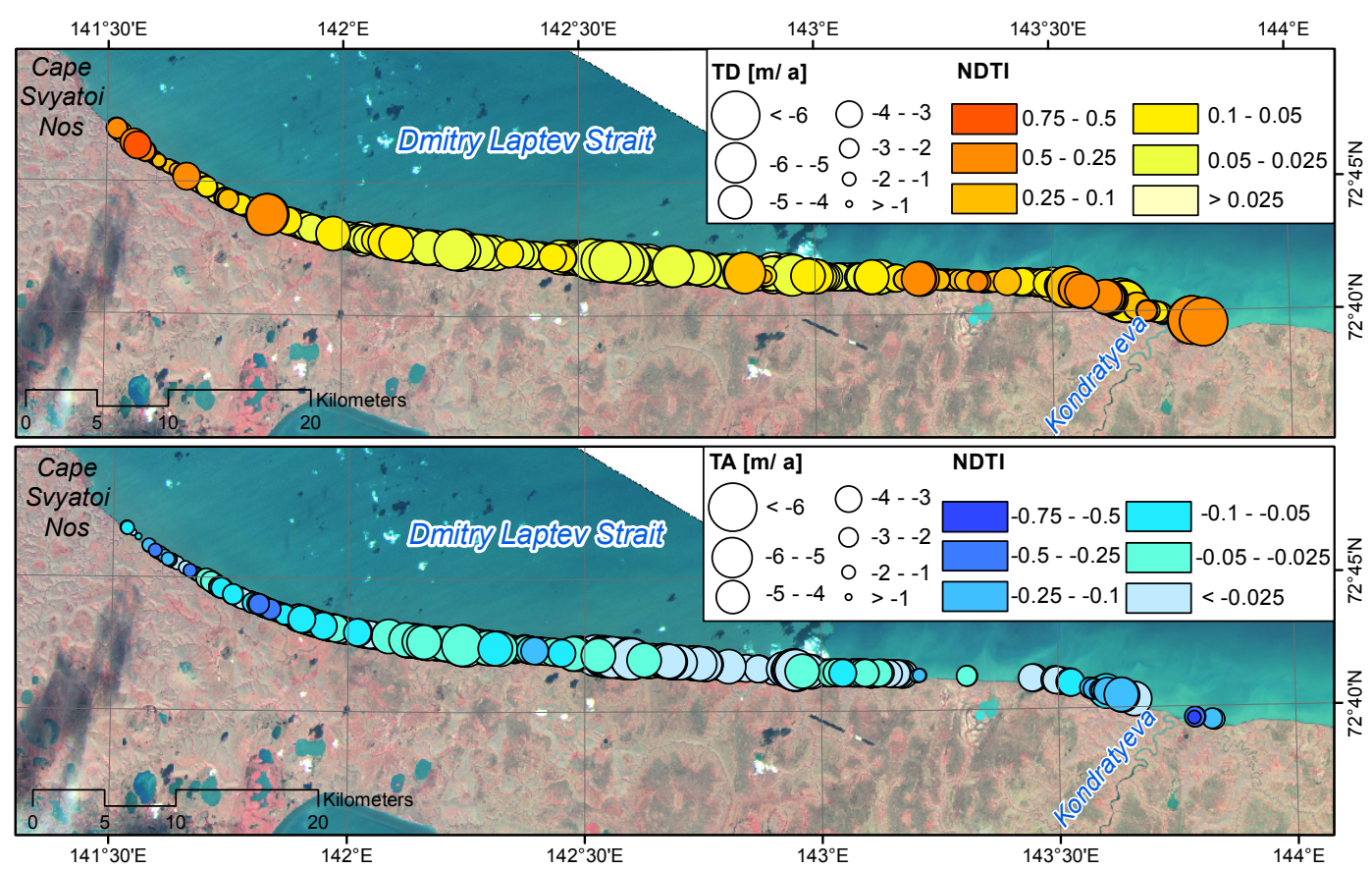

Fig. 9. Thematic map of coastal thermo-erosion transect data along the studied coastline of Oyogos Yar (Yana-Indigirka lowland west of Cape Svyatoi Nos; Dmitry Laptev Strait). The upper map segment illustrates colour coded positive NDTI values associated with prevailing thermo-denudation (TD), the lower map illustrates colour coded negative NDTI values associated with prevailing thermo-abrasion (TA). The symbol size is equivalent to erosion values.

yedoma cliffs of $-1.7 \mathrm{ma}^{-1}$ and $-1.9 \mathrm{ma}^{-1}$ over a $25 \mathrm{yr}$ period (1974-1999). Our 43 yr long-term record for these particular two sites show the same values, although when examined across all eroding yedoma coasts on Buor Khaya, TD is only $-1 \mathrm{ma}^{-1}$.

Most of the Oyogos Yar coastline erodes via formation of thermo-erosional niches and block failure along ice-wedge polygons, as is typical for flat, low-lying alas coasts. The yedoma hills of Oyogos Yar adjacent to the Kondratyeva River mouth are very ice-rich and simply thaw away under the influence of TD (Are et al., 2005), resulting in large positive NDTI values (Fig. 9). Additionally, the lower Ice Complex boundary is a.s.l. and TA may be slower due to the low ground-ice content in underlying layers. Kaplina (2011) reports that alas deposits and the layers underlying the Ice Complex dip eastwards from Cape Svyatoi Nos. This dipping is probably responsible for gradual changes in erosion rates along the Oyogos Yar coast where the material in contact with sea water changes. Our long-term coastal erosion rates along the Oyogos Yar coast are of comparable magnitude to those found by Pizhankova and Dobrynina (2010) on the opposite side of the Dmitry Laptev Strait. On Bolshoy Lyakhovsky Island, where only $46 \%$ of the coastline is erosive, yedoma and alas coasts are eroding at $-5.3 \mathrm{ma}^{-1}$ and $-4.1 \mathrm{ma}^{-1}$, respectively, where the lower Ice Complex boundary is at or below sea level. Erosion is slower $\left(-3.4 \mathrm{ma}^{-1}\right.$ and $\left.-3.2 \mathrm{ma}^{-1}\right)$ where ice-poor sediments crop out at sea level.

In addition to averaged thermo-erosion rates, coastal erosion can be quantified by area of land loss, like Mars and Houseknecht (2007) have done, using raster-based quantification. As a case study, we calculated land loss using the vectorised coastlines of the Mamontov Klyk data set. Along $55.7 \mathrm{~km}$ of coastline effective land loss due to TD is $4.44 \mathrm{~km}^{2}$ over the $39.8 \mathrm{yr}$ mean observation period. Mean cliff-top erosion was $-79.7 \mathrm{~m}$ or $-2.0 \mathrm{ma}^{-1}$. Our DSAS transect data for this coastline segment, on the other hand, show consistent mean TD values of $-81.0 \mathrm{~m}$ and $-2.1 \mathrm{ma}^{-1}$, respectively. Using transects at $50 \mathrm{~m}$ intervals is thus sufficient method for determining coastal erosion. Based on our transect data we calculate mean annual land lost along the Mamontov Klyk coast is 2050, on Buor Khaya 550 and along the Oyogos Yar coast $3390 \mathrm{~m}^{2} \mathrm{~km}^{-1} \mathrm{a}^{-1}$.

\subsection{Recent coastal thermo-erosion rates}

Compared to the long-term, coastal erosion rates over the past one to four years were more rapid, even when considering higher uncertainties of \pm 1.41 and $\pm 1.22 \mathrm{ma}^{-1}$ for TD and TA, respectively. More rapid recent erosion rates, particularly of short-term TA rates (Fig. 7), indicate the greater marine influence at Mamontov Klyk and Oyogos Yar. On the Buor Khaya Peninsula, recent TD rates are more rapid than long-term observations (Fig. 7) and in places 
of up to $-16 \mathrm{ma}^{-1}$. However, short-term measurements on Buor Khaya exist only for yedoma coasts, where TD generally predominates but which do not represent the majority of the coastline.

In general, more rapid erosion over the past few years may reflect the normal temporal variability of coastal erosion rates, or might reflect an increase in rates over the long-term mean. Examples of observed temporal variability exist: Sisko (1970) finds a four year cyclicity of thermo-abrasion intensity on the island of New Siberia. Jones et al. (2009b) document the episodic nature of block collapse. Vasiliev et al. (2011) record a $20 \mathrm{yr}$ cyclicity of erosion along the western coast of the Yamal Peninsula, where the mean coastal erosion rate is $-1.7 \mathrm{ma}^{-1}$ and does not experience direct climate forcing. According to Hoque and Pollard (2009), variations in backshore height and ground-ice composition generate different potential failure planes. Adopted to our study sites, we believe different relative intensities of TD and TA on low-lying alas are limited by low cliff heights and low ground-ice content (Tab. 4), hence rapidly eroding alas coasts (Oyogos Yar) are likely to fail along the vertical plane and consequently have NDTI values around zero, while alas coasts eroding slowly (Buor Khaya) may exhibit a larger negative as well as positive NDTI values. For yedoma coasts the interdependence of TD and TA is more complicated, due to the large ground-ice contents and alternating stratification of sediment and peat layers, which is why high yedoma may fail along an inclined plane causing differences in TD and TA rates.

Intermittent intense coastal erosion activity cause more sediment to be removed from the cliff bottom by waves, slowing down intensity temporally before a phase of higher activity can start again. However, remote sensing time series analyses of Jones et al. (2009a) reveal a steady increase of coastal erosion intensity on the Alaska Beaufort Sea coast, with almost a doubling of rates to $-13.6 \mathrm{ma}^{-1}$ recently. Despite the episodic nature of thermo-erosion, we observed short-term rates of both TD and TA are more rapid than longterm rates for all three sites at the same time, suggesting a larger spatial forcing that affects all three sites.

\subsection{Normalized Difference Thermo-erosion Index (NDTI) and relevance of its components}

Nearly identical long-term TD and TA rates, as well as their variations, suggest that long-term evolution of the coasts is a continuous process, where cliff-bottom and cliff-top erosion are interdependent. This is questioned by Are (2012). Shur et al. (2002) also describe the phenomenon of different behaviour of yedoma cliffs regarding relative intensities of erosion along the cliff top and cliff-bottom line. Are (2012) notices that TD along yedoma hills is usually faster than TA, and concludes that cliff-top erosion does not depend on sea erosion, and that the cliff-top line cannot be regarded as the primary coastline. NDTI permits us to evalu- ate the relative importance of TD and TA to the mechanics of arctic coastal erosion.

Along coasts with horizontally continuous ground-ice layers like on the Yamal and Yugorsky peninsulas (Streletskaya et al., 2006; Leibman et al., 2008) and in the Canadian Arctic (Fritz et al., 2011), a decoupling of cliff-top and cliff-bottom erosion is observed in thermo-cirques (Kizyakov et al., 2006), and retrogressive thaw slumps (Lantuit and Pollard, 2005). On Herschel Island in NW Canada, Lantuit and Pollard (2008) observe average headwall erosion rates of $-9.6 \mathrm{ma}^{-1}$ that outpace mean lower coastline erosion of only $-0.6 \mathrm{ma}^{-1}$. This would equal a high NDTI value of 0.88 . Our NDTI data for TD along yedoma coasts is an order of magnitude lower. This suggests that TD and TA are coupled by the presence of segregated ground-ice and syngenetic-ice wedges in permafrost deposits, such as Ice Complex, that extend downward to the water level. If so, NDTI serves as an indirect geomorphometrical parameter for vertical ground-ice distribution along eroding permafrost coasts.

To interpret our observations of recently more rapid coastal erosion rates, we primarily take advantage of the NDTI concept, as a proxy for the quality of thermo-erosion. Mean NDTI data was positive over the long-term and negative over the short-term observation period at Oyogos Yar, and vice versa at Buor Khaya. NDTI along the Mamontov Klyk coast was similar for the long and short-term periods, in both cases reflecting the equivalence of TD and TA. From these data we hypothesize that, depending on the site characteristics of either offshore-marine (Mamontov Klyk and Oyogos Yar) or bay-marine (Buor Khaya), changing environmental conditions will have various impacts on coastal erosion. Boike et al. (2013) record higher air temperatures during the very warm summer of 2010 in the Laptev Sea region. Markus et al. (2009) observe an increase in the duration of the sea ice melt season for the Laptev/East Siberian seas of 10 days per decade for the last $30 \mathrm{yr}$. Both may have contributed to increasing speeds of TD and TA as observed here.

Mass flux rates increase most when coastal thermo-erosion increases with an NDTI close to 0 (Günther et al., 2012). Rapid TD depends on the exposure of an ice wall. The rate of mass flux in the coastal waters can increase if TD forcing changes by active layer deepening (Shiklomanov et al., 2012), higher precipitation, and air temperatures. However, as TD progresses, the cliff slope becomes more gentle, less ice is exposed and TD becomes self-limiting. TA is limited by material removal through waves, which can also limit the effectiveness of TD. Therefore, we suggest that a longer period of open coastal waters and its consequently higher wave energy, could prove to be the major factor regulating whether the recently observed rapid erosion will remain at this level. 


\subsection{Impact of coastal thermo-erosion on land-to-shelf interactions and carbon fluxes}

All studied coastline segments are bordered by large accumulation zones, illustrating the removal and transportation of erosion products by currents. Coastal erosion is an agent of land-shelf interactions, influencing drainage development in the coastal hinterland. The drainage network in our study sites is developed towards the coast, as described above. Progression of the coastline towards the mainland leads to rising local relief energy and subsequent compensating geomorphological processes. Further development of drainage systems in the coastal lowlands will result in drainage events of thermokarst lakes. Van Huissteden et al. (2011) highlight the importance of thermokarst lake drainage on permafrost ecosystems. Jones et al. (2011) dedicate attention to thermokarst lake expansion and drainage on the Seward Peninsula, Alaska. They find total lake surface area is currently decreasing by $15 \%$. Günther et al. (2010) observe lake drainage events on yedoma hills in the Lena Delta, the half of which were caused by lake tapping due to river bank erosion. Lakes in this area are limited in their future development by areal and stratigraphical constraints (Morgenstern et al., 2011), and consequently lake drainage was outpacing lake expansion. This example illustrates the far reaching impact of coastal erosion on adjacent territories.

Grigoriev (2004) suggest that the entire Mamontov Klyk coast is one of the most active in terms of coastal erosion and that, as a result, it plays an important role in the sediment and organic carbon balance of the Laptev Sea. In fact, the relative proportions of yedoma and alas are highest in favor of nondegraded yedoma at Mamontov Klyk, representing a large pool of clastic material and organic carbon by itself, and a source of these due to rapid coastal erosion rates.

Along the west coast of the Buor Khaya Peninsula we see alternating alas basins with yedoma hills. The draining effect of the sea is well-documented by recently drained thermokarst lakes in coastal proximity. Based on RapidEye data, we estimate the limnicity along the Buor Khaya west coast due to large thermokarst lakes is $\approx 11 \%$. Recently strongly increased TD rates are likely to create pathways for lake drainage and effectively for sea expansion, depending on lake depth probably also in the form of thermokarst lagoons, enlarging the specific coastline length.

Regarding the coastal lowland at Oyogos Yar, Gavrilov et al. (2006) comment that, the draining effect of the sea in this area of neotectonic subsidence is illustrated by the almost complete absence of thermokarst lakes within a buffer of $10 \mathrm{~km}$ landwards. Because of the almost flat topography and mature thermokarst relief at Oyogos Yar, we therefore do not expect more rapid coastal erosion rates to have greater impacts on the landscape drainage system. However, as a site of formerly thick Ice Complex accumulation followed by marine transgression (Romanovskii et al., 2000), the Dmitry Laptev Strait provides a large potential of continuous mate- rial resuspension (Are et al., 2008), where increased material fluxes due to higher TA rates along the Oyogos Yar coast will have great influence on water quality and turbidity in this mixing path between Laptev and East Siberian Sea.

We have limited our coastal erosion and carbon flux analyses only to eroding coastlines of the Ice Complex, i.e. those sections for which TOC contents and erosion rates are higher than average for the Laptev Sea and for the Arctic Ocean. Ping et al. (2011) classify the Alaska Beaufort Sea coastline into 8 geomorphic units and find annual organic carbon fluxes from coastal erosion range from 21 to 163 and averaged $63 \mathrm{~kg}$ per meter coastline, matching with previous estimates (Brown et al., 2003). In our study a distinction was made between coastline segments that are composed of Ice Complex and alas deposits. In this way, we found annual carbon flux ranged from $88 \pm 21$ to $800 \pm 61 \mathrm{t}$ per km of coastline per year. To generate the magnitude of coastal erosion carbon fluxes described in other studies (e.g. $12 \mathrm{Tg} \mathrm{a}^{-1}$ for the Laptev Sea in Vonk et al., 2012), would require either more than $34000 \mathrm{~km}$ of similar Ice Complex coastline or erosion rates more than 18 times higher than the long-term rates observed here. Our study covers $10 \%$ of the entire Ice Complex coastline of the Laptev Sea and includes a wide range of different proportions of regional ice complex degradation, rather than relying on a point measurement. Since we focused our study systematically on coasts with active ongoing coastal thermo-erosion, well distributed along the mainland coast, our estimates of organic carbon fluxes from Ice Complex deposits over the entire Laptev Sea, might be considered not as conservative, although they are only a third the amount as previously stated in preliminary estimations of Grigoriev et al. (2004). However, if we had extrapolated our site-specific carbon fluxes to the Laptev Sea based only on the data from Buor Khaya, this would have resulted in a value ten times lower than if calculated exclusively based on the Oyogos Yar data $\left(0.12 \times 10^{6} \pm 0.03 \mathrm{t}\right.$ compared to $1.12 \times 10^{6} \pm 0.08 \mathrm{t}$ ). Although our estimates of annual carbon flux $\left(0.66 \times 10^{6} \pm 0.05 \mathrm{t}\right)$ resulting from coastal erosion in the Laptev Sea compares well with the middle of these two extremes, upscaling of TOC fluxes from coastal erosion should include cautious appraisal of Ice Complex coastline length, effectively eroded volumes due to the different impact of TD and TA, and the spatial and temporal heterogeneity of coastal thermo-erosion.

In a study of the five largest arctic rivers, paying particular attention to the historical undersampled spring melt, Raymond et al. (2007) quantify the mean annual dissolved organic carbon flux from the Lena River as $5.83 \times 10^{6} \mathrm{t}$, exceeding coastal carbon fluxes in the Laptev Sea region by a multiple. However, whereas rivers transport young organic carbon, largely derived from recently fixed carbon in plant litter and upper soil horizons (Benner et al., 2004), coastal thermoerosion mobilizes old carbon stored in permafrost, which can be considered as an additional source to the present carbon cycle. In addition, riverine dissolved organic carbon is 
released over a relatively confined area to the shelf sea during the spring freshet, when water temperatures are low, whereas coastal carbon is released in late summer in a distributed fashion to the coastal waters. Changes to coastally derived fluxes may therefore have a greater impact on ecosystem functioning.

\section{Conclusions}

In this study we present coastal thermo-erosion rates of three mainland sites with different degrees of permafrost degradation in the Laptev Sea region. Our long-term data are derived from change detection using remote sensing data and serve as a benchmark for intersite comparison and for comparison with modern coastal erosion rates. Across all study sites, recent erosion rates were at least 1.6 times higher than the long-term mean. Coastline position changes varied between 0 and $-21 \mathrm{ma}^{-1}$, illustrating the high variability of coastal thermo-erosion.

By examining cliff-top (TD) and cliff-bottom (TA) erosion separately, we distinguish between processes responsible for thermo-erosion. TD leads to high erosion rates when nearsurface ice-rich layers are exposed along the cliff-top line, but is not necessarily accompanied by larger eroded volumes unless TA is also rapid. The Normalized Difference Thermoerosion Index (NDTI) is a dimensionless index that qualitatively describes the relative proportions of TD and TA. Positive NDTI values indicate prevailing TD and negative NDTI that TA dominates. Despite spatially variable relative intensities of TD and TA at each study site, when considered as a set, NDTI values indicate that TD and TA are of equal importance to thermo-erosion on a regional scale. High ice contents of the yedoma coasts couple the processes since the entire coastal cliff profile is super-saturated with respect to ice, largely due to thick syngenetic ice wedges from the cliff top down to sea level. TD and TA along low-lying alas coasts are strongly coupled by topographic constraints.

The results of our planimetric coastal erosion quantification and backshore height information from DEMs were used for calculating mass fluxes in the coastal zone. We showed that thermo-erosion of coasts composed of Pleistocene Ice Complex permafrost deposits at our study sites along the western and south-central Laptev Sea coast and the Dmitry Laptev Strait released on average $471 \pm 32.9$ tonnes of organic carbon per km of coastline per year. Upscaling our observations to the entire Ice Complex coastline in the Laptev Sea region, corresponds to a total annual carbon flux released from coastal erosion about $0.66 \times 10^{6} \pm 0.05 \mathrm{t}$, which is substantially lower than some previous estimates and corresponds to one-eighth of the carbon transported by the Lena River, but is spatially and temporally more evenly distributed along the shallow Laptev Sea shelf.

The coastlines examined here are one of the most ice and carbon rich in the Arctic, and therefore particularly sensi- tive to climate change, while playing a potential role as a feedback to the climate cycle. If coastal erosion and the concomitant release of carbon to the shelf seas are increasing as a result of recent warming and sea ice changes, our results suggest that these increases are only recent but represent an almost doubling of erosion rates on a decadal timescale or less.

Acknowledgements. We thank J. Strauss for his contribution of organic carbon and ice contents of Ice Complex deposits. We greatly appreciate the logistical support of our partners from the Tiksi Hydrobase, the Lena Delta Reserve, and from the Arctic and Antarctic Research Institute, St. Petersburg - Russian Federation. RapidEye imagery was provided by the German Aerospace Center through the RapidEye Science Archive. ALOS PRISM and KOMPSAT-2 data were provided by the European Space Agency (ESA project ID 4133, ESA ADEN, ID 3616). SPOT-5 imagery were provided by SPOT Planet Action - an Astrium GEO initiative (project: Coastal erosion in East Siberia). The German Ministry of Science and Education funded this research through the Potsdam Research Cluster for Georisk Analysis, Environmental Change and Sustainability (PROGRESS). This work was also made possible by support from the German Helmholtz Association through a Joint Russian-German Research Group (HGF-JRG 100).

Edited by: I. Bussmann

\section{References}

AMAP: Snow, Water, Ice and Permafrost in the Arctic (SWIPA): Climate Change and the Cryosphere, Arctic Monitoring and Assessment Programme (AMAP), Oslo, Norway, available at: www.amap.no, 2011.

Are, F. E.: The reworking of shorelines in the permafrost zone, in: Proceedings of the Second International Conference on Permafrost, Yakutsk, USSR, July 1973, USSR Contribution, US National Academy of Sciences, Washington, DC, 59-62, 1978.

Are, F. E.: Thermal abrasion of sea coasts (part 1), Polar Geogr. Geol., 12, 1-86, doi:10.1080/10889378809377343, from: Termoabraziya morskikh beregov, Moscow, Nauka, 1980, 158 pp., 1988a.

Are, F. E.: Thermal abrasion of sea coasts (part 2), Polar Geogr. Geol., 12, 87-157, doi:10.1080/10889378809377352, from: Termoabraziya morskikh beregov, Moscow, Nauka, 1980, 158 pp., 1988b.

Are, F. E.: The role of coastal retreat for sedimentation in the Laptev Sea, in: Land-Ocean Systems in the Siberian Arctic, edited by: Kassens, H., Bauch, H. A., Dmitrenko, I. A., Eicken, H., Hubberten, H.-W., Melles, M., Thiede, J., and Timokohov, L. A., Springer, Berlin Heidelberg, 287-295, 1999.

Are, F. E.: Razrushenie beregov arkticheskikh primorskikh nizmennostei (Coastal erosion of the Arctic lowlands), Academic publishing house "Geo", Novosibirsk, 2012.

Are, F. E., Grigoriev, M. N., Hubberten, H.-W., Rachold, V., Razumov, S. O., and Schneider, W.: Coastal erosion studies in the Laptev Sea, in: Russian-German Cooperation System Laptev Sea: The Expedition Lena 1999, edited by: Rachold, V., vol. 354, Reports on Polar and Marine Research, Alfred Wegener Insti- 
tute, available at: http://hdl.handle.net/10013/epic.10357, chap. 4.3, 65-74, 2000.

Are, F., Grigoriev, M. N., Hubberten, H.-W., Rachold, V., Razumov, S. O., and Schneider, W.: Comparative shoreface evolution along the Laptev Sea coast, Polarforschung, 70, 135-150, available at: http://hdl.handle.net/10013/epic.29866, 2002.

Are, F. E., Grigoriev, M. N., Hubberten, H.-W., and Rachold, V.: Using thermoterrace dimensions to calculate the coastal erosion rate, Geo-Mar. Lett., 25, 121-126, doi:10.1007/s00367-0040193-y, 2005.

Are, F. E., Reimnitz, E., Grigoriev, M. N., Hubberten, H.-W., and Rachold, V.: The influence of cryogenic processes on the erosional arctic shoreface, J. Coast. Res., 24, 110-121, doi:10.2112/05-0573.1, 2008.

Asplin, M. G., Galley, R., Barber, D. G., and Prinsenberg, S.: Fracture of summer perennial sea ice by ocean swell as a result of Arctic storms, J. Geophys. Res., 117, C06025, doi:10.1029/2011JC007221, 2012.

Benner, R., Benitez-Nelson, B., Kaiser, K., and Amon, R. M. W.: Export of young terrigenous dissolved organic carbon from rivers to the Arctic Ocean, Geophys. Res. Lett., 31, L05305, doi:10.1029/2003GL019251, 2004.

Boike, J., Kattenstroth, B., Abramova, K., Bornemann, N., Chetverova, A., Fedorova, I., Fröb, K., Grigoriev, M., Grüber, M., Kutzbach, L., Langer, M., Minke, M., Muster, S., Piel, K., Pfeiffer, E.-M., Stoof, G., Westermann, S., Wischnewski, K., Wille, C., and Hubberten, H.-W.: Baseline characteristics of climate, permafrost, and land cover from a new permafrost observatory in the Lena River Delta, Siberia (1998-2011), Biogeosciences, 10, 2105-2128, doi:10.5194/bg10-2105-2013, 2012.

Brown, J., Jorgenson, M. T., Smith, O. P., and Lee, W.: Long-term rates of erosion and carbon input, Elson Lagoon, Barrow, Alaska, in: Permafrost: Proceedings of the 8th International Conference on Permafrost, edited by: Phillips, M., Springman, S. M., and Arenson, L. U., the Netherlands: AA Balkema Publishers, 101106, 2003.

Charkin, A. N., Dudarev, O. V., Semiletov, I. P., Kruhmalev, A. V., Vonk, J. E., Sánchez-García, L., Karlsson, E., and Gustafsson, Ö.: Seasonal and interannual variability of sedimentation and organic matter distribution in the Buor-Khaya Gulf: the primary recipient of input from Lena River and coastal erosion in the southeast Laptev Sea, Biogeosciences, 8, 2581-2594, doi:10.5194/bg-8-2581-2011, 2011.

Comiso, J. C., Parkinson, C. L., Gersten, R., and Stock, L.: Accelerated decline in the Arctic sea ice cover, Geophys. Res. Lett., 35, L01703, doi:10.1029/2007GL031972, 2008.

Dmitrenko, I. A., Kirillov, S. A., Tremblay, L. B., Kassens, H., Anisimov, O. A., Lavrov, S. A., Razumov, S. O., and Grigoriev, M. N.: Recent changes in shelf hydrography in the Siberian Arctic: potential for subsea permafrost instability, J. Geophys. Res., 116, C10027, doi:10.1029/2011JC007218, 2011.

Drachev, S. S., Savostin, L. A., Groshev, V. G., and Bruni, I. E.: Structure and geology of the continental shelf of the Laptev Sea, Eastern Russian Arctic, Tectonophysics, 298, 357-393, doi:10.1016/S0040-1951(98)00159-0, 1998.

Dunaev, N. N. and Nikiforov, S. L.: Shelf i berega arkticheskikh morei (Shelf and coasts of arctic seas), in: Geoekologiya shelfa i beregov morei Rossii (Geoecology of Shelf and Coasts of Rus- sian Seas), edited by: Aibulatov, N. A., Noosphera, Moscow, chap. 2, 27-242, 2001.

Dupeyrat, L., Costard, F., Randriamazaoro, R., Gailhardis, E., Gautier, E., and Fedorov, A.: Effects of ice content on the thermal erosion of permafrost: implications for coastal and fluvial erosion, Permafrost Periglac., 22, 179-187, doi:10.1002/ppp.722, 2011.

Ehlers, M., Klonus, S., Åstrand, P., and Rosso, P.: Multi-sensor image fusion for pansharpening in remote sensing, International J. Image Data Fus., 1, 25-45, doi:10.1080/19479830903561985, 2010.

Forbes, D. L.: State of the Arctic Coast 2010 - Scientific Review and Outlook, International Arctic Science Committee, LandOcean Interactions in the Coastal Zone, Arctic Monitoring and Assessment Programme, International Permafrost Association, Helmholtz-Zentrum, Geesthacht, Germany, available at: http:// arcticcoasts.org, 2011.

Fraser, C. S. and Ravanbakhsh, M.: Georeferencing accuracy of GeoEye-1 imagery, Photogramm. Eng. Rem. S., 75, 634-638, 2009.

Fritz, M., Wetterich, S., Meyer, H., Schirrmeister, L., Lantuit, H., and Pollard, W. H.: Origin and characteristics of massive ground ice on Herschel Island (western Canadian Arctic) as revealed by stable water isotope and hydrochemical signatures, Permafrost Periglac., 22, 26-38, doi:10.1002/ppp.714, 2011.

Gavrilov, A. V., Romanovskii, N. N., and Hubberten, H.-W.: Paleogeograficheskii scenarii poslelednikovoi transgressii na shelfe Morya Laptevykh (Paleogeographic scenario of the postglacial transgression on the Laptev Sea shelf), Kriosfera Zemli (Earth's Cryosphere), 10, 39-50, available at: http://www.izdatgeo.ru/ pdf/krio/2006-1/39.pdf, 2006.

Grigoriev, M. N.: Periglacial studies around Cape Mamontov Klyk - Studies of coastal dynamics and subsea permafrost, in: Russian-German Cooperation System Laptev Sea: The Expedition Lena-Anabar 2003, edited by: Schirrmeister, L., vol. 489, Reports on Polar and Marine Research, Alfred Wegener Institute, available at: http://hdl.handle.net/10013/epic.10494, chap. 4.7, 139-150, 2004.

Grigoriev, M. N.: Kriomorphogenez i litodinamika pribrezhnoshelfovoi zony morei Vostochnoi Sibiri (Cryomorhogenesis and lithodynamics of the East Siberian near-shore shelf zone), Habilitation thesis, SB RAS Permafrost Institute, Yakutsk, 2008.

Grigoriev, M. N. and Rachold, V.: The degradation of coastal permafrost and the organic carbon balance of the Laptev and East Siberian Seas, in: Permafrost: Proceedings of the 8th International Conference on Permafrost, edited by: Phillips, M. and Springman, S.M. and Arenson, L.U., the Netherlands: AA Balkema Publishers, 319-324, 2003.

Grigoriev, M. N., Are, F. E., Hubberten, H.-W., Rachold, V., Razumov, S. O., and Schneider, W.: Onshore coastal studies - coastal dynamics at key sites of the New Siberian Islands, Dmitry Laptev Strait, and Buor Khaya Bay, in: Russian-German Cooperation System Laptev Sea: The Expedition Lena 2002, edited by: Grigoriev, M. N., Rachold, V., Bolshiyanov, D. Y., Pfeiffer, E.-M., Schirrmeister, L., Wagner, D., and Hubberten, H.-W., vol. 466, Reports on Polar and Marine Research, Alfred Wegener Institute, available at: http://hdl.handle.net/10013/epic.10471, chap. 5.3.3, 326-329, 2003. 
Grigoriev, M. N., Rachold, V., Schirrmeister, L., and Hubberten, H.W.: Organic carbon input to the Arctic Seas through coastal erosion, in: The Organic Carbon Cycle in the Arctic Ocean: Present and Past, edited by: Stein, R. and Macdonald, R. W., Springer, Berlin, chap. 2.3, 37-65, 2004.

Grigoriev, M. N., Razumov, S. O., Kunitzky, V. V., and Spektor, V. B.: Dinamika Beregov Vostochnykh Arkticheskikh Morei Rossii: Osnovnye Faktory, Zakonomernosti i Tendencii (Dynamics of the Russian East Arctic Sea coast: major factors, regularities and tendencies), Kriosfera Zemli (Earth's Cryosphere), 10 (4), 74-94, available at: http://www.izdatgeo.ru/pdf/krio/2006-4/ 74.pdf, 2006.

Grigoriev, M. N., Kunitsky, V. V., Chzhan, R. V., and Shepelev, V. V.: On the variation in geocryological, landscape and hydrological conditions in the Arctic zone of East Siberia in connection with climate warming, Geogr. Natur. Resour., 30, 101106, doi:10.1016/j.gnr.2009.06.002, 2009.

Grosse, G., Schirrmeister, L., Kunitsky, V. V., and Hubberten, H.$\mathrm{W}$.: The use of CORONA images in remote sensing of periglacial geomorphology: an illustration from the NE Siberian coast, Permafrost Periglac., 16, 163-172, doi:10.1002/ppp.509, 2005.

Grosse, G., Schirrmeister, L., and Malthus, T. J.: Application of Landsat-7 satellite data and a DEM for the quantification of thermokarst-affected terrain types in the periglacial Lena-Anabar coastal lowland, Polar Res., 25, 51-67, doi:10.1111/j.1751-8369.2006.tb00150.x, 2006.

Grosse, G., Romanovsky, V., Jorgenson, T., Walter Anthony, K. M., Brown, J., and Overduin, P. P.: Vulnerability and feedbacks of permafrost to climate change, Eos Trans. AGU, 92, 73-74, doi:10.1029/2011EO090001, 2011.

Günther, F., Ulrich, M., Morgenstern, A., and Schirrmeister, L.: Planimetric and volumetric thermokarst change detection on ice rich permafrost, using remote sensing and field data, in: Abstracts from the Third European Conference on Permafrost, edited by: Mertes, J. R., Christiansen, H. H., and Etzelmüller, B., The University Centre in Svalbard, available at: http://hdl.handle. net/10013/epic.35490, 2010.

Günther, F., Overduin, P. P., and Sandakov, A. V.: Topographical surveys for coastal dynamics studies, in: Russian-German Cooperation System Laptev Sea: The Expedition Eastern Laptev Sea - Buor Khaya Peninsula 2010, edited by: Wetterich, S., Overduin, P. P., and Grigoriev, M. N., vol. 629, Reports on Polar and Marine Research, Alfred-Wegener-Institute, chap. 4, 17-34, available at: http://hdl.handle.net/10013/epic.37743, 2011.

Günther, F., Overduin, P. P., Sandakov, A. V., Grosse, G., and Grigoriev, M. N.: Thermo-erosion along the Yedoma Coast of the Buor Khaya Peninsula, Laptev Sea, East Siberia, in: Proceedings of the Tenth International Conference on Permafrost, Salekhard, Yamal-Nenets Autonomous District, Russia, June 25-29, edited by: Hinkel, K. M., vol. 1, International Contributions, available at: http://epic.awi.de/30828/, 137-142, 2012.

Hellmann, L., Tegel, W., Eggertsson, Ó., Schweingruber, F. H., Blanchette, R., Kirdyanov, A., Gärtner, H., Büntgen, U.: Tracing the origin of Arctic driftwood, J. Geophys. Res.-Biogeosciences, 118, 68-76, doi:10.1002/jgrg.20022, 2013.

Hoque, M. A. and Pollard, W. H.: Arctic coastal retreat through block failure, Can. Geotechn. J., 46, 1103-1115, doi:10.1139/T09-058, 2009.
Imaeva, L. P., Kozmin, B. M., Sergeyenko, A. I., Belolyubskii, I. N., and Siegert, C.: Noveyshie struktury, stratigrafiya kvartera i sovremennaya geodinamika territorii Arkticheskogo sektora probrezhno-shelfovoi zony Severnogo Verkhoyana (Severovostok Yakutii) - (Modern structures, quaternary stratigraphy and recent geodynamics in the Arctic sector of the Northern Verkhoyan coastal shelf zone (North of East Yakutia)), Bulletin of the comission on studies of the quaternary period, 67, 6-19, 2007.

Jones, B. M., Arp, C. D., Jorgenson, M. T., Hinkel, K. M., Schmutz, J. A., and Flint, P. L.: Increase in the rate and uniformity of coastline erosion in Arctic Alaska, Geophys. Res. Lett., 36, L03503, doi:10.1029/2008GL036205, 2009a.

Jones, B. M., Arp, C. D., Beck, R. A., Grosse, G., Webster, J. M., and Urban, F.: Erosional history of Cape Halkett and contemporary monitoring of bluff retreat, Beaufort Sea coast, Alaska, Polar Geogr., 32, 129-142, doi:10.1080/10889370903486449, 2009 b.

Jones, B. M., Grosse, G., Arp, C. D., Jones, M. C., Walter Anthony, K. M., and Romanovsky, V. E.: Modern thermokarst lake dynamics in the continuous permafrost zone, northern Seward Peninsula, Alaska, J. Geophys. Res., 116, G00M03, doi:10.1029/2011JG001666, 2011.

Kamiya, I.: Reduction of JPEG Noise from the ALOS PRISM Products, Bulletin of the Geographical Survey Institute, 55, 31-38, 2008.

Kaplina, T. N.: Nekotorye osobennosti razmyva beregov, slozhennykh mnogoletnemerzlymi gornymi porodami (Some features of coastal thermoerosion of frozen bluffs), Questions of sea coast research, Publishing House of the USSR Academy of Sciences, Moscow, 113-117, 1959.

Kaplina, T. N.: Drevnie alasnye kompleksy Severnoi Yakutii - soobshchenie 2 (Ancient alas complexes of Northern Yakutia - part 2), Kriosfera Zemli (Earth's Cryosphere), 15, 20-30, available at: http://www.izdatgeo.ru/pdf/krio/2011-3/20.pdf, 2011.

Kholodov, A., Gilichinsky, D., Ostroumov, V., Sorokovikov, V., Abramov, A., Davydov, S., and Romanovsky, V.: Regional and local variability of modern natural changes in permafrost temperature in the Yakutian coastal lowlands, Northeastern Siberia, in: Proceedings of the Tenth International Conference on Permafrost, Salekhard, Yamal-Nenets Autonomous District, Russia, 25-29 June, edited by: Hinkel, K., vol. 1, International Contributions, 203-207, 2012.

Kizyakov, A. I., Leibman, M. O., and Perednya, D. D.: Destruktivnye rel'efoobrazuyushie processy poberezhii arkticheckikh ravnin c plastovymi podzemnymi l'dami (Destructive reliefforming processes at the coasts of the arctic plains with tabular ground ice), Kriosfera Zemli (Earth's Cryosphere), 10, 7989, available at: http://www.izdatgeo.ru/pdf/krio/2006-2/79.pdf, 2006.

Klyuev, Y. V.: Termicheskaya abraziya pribrezhnoi polosy polyarnykh morey (Thermal erosion of the coastal zone of polar seas), Izvestiya vsesoyuznogo geograficheskogo obshchestva, 102, 129-135, 1970.

Lantuit, H. and Pollard, W. H.: Temporal stereophotogrammetric analysis of retrogressive thaw slumps on Herschel Island, Yukon Territory, Nat. Hazards Earth Syst. Sci., 5, 413-423, doi:10.5194/nhess-5-413-2005, 2005.

Lantuit, H. and Pollard, W. H.: Fifty years of coastal erosion and retrogressive thaw slump activity on Herschel Island, southern 
Beaufort Sea, Yukon Territory, Canada, Geomorphology, 95, 84102, doi:10.1016/j.geomorph.2006.07.040, 2008.

Lantuit, H., Rachold, V., Pollard, W. H., Steenhuisen, F., Ødegård, R., and Hubberten, H.-W.: Towards a calculation of organic carbon release from erosion of Arctic coasts using non-fractal coastline datasets, Mar. Geol., 257, 1-10, doi:10.1016/j.margeo.2008.10.004, 2009.

Lantuit, H., Atkinson, D., Overduin, P. P., Grigoriev, M. N., Rachold, V., Grosse, G., and Hubberten, H.-W.: Coastal erosion dynamics on the permafrost-dominated Bykovsky Peninsula, north Siberia, 1951-2006, Polar Res., 30, 7341, doi:10.3402/polar.v30i0.7341, 2011a.

Lantuit, H., Overduin, P. P., Couture, N., Wetterich, S., Are, F., Atkinson, D., Brown, J., Cherkashov, G., Drozdov, D., Forbes, D. L., Graves-Gaylord, A., Grigoriev, M. N., Hubberten, H.-W., Jordan, J., Jorgenson, T., Ødegård, R. S., Ogorodov, S., Pollard, W. H., Rachold, V., Sedenko, S., Solomon, S., Steenhuisen, F., Streletskaya, I., and Vasiliev, A.: The Arctic coastal dynamics database: a new classification scheme and statistics on arctic permafrost coastlines, Estuar. Coast., 35, 383-400, doi:10.1007/s12237-010-9362-6, $2011 \mathrm{~b}$.

Leibman, M., Gubarkov, A., Khomutov, A., Kizyakov, A., Vanshtein, B.: Coastal processes at the tabular-ground-ice-bearing area, Yugorsky Peninsula, Russia, in: Proceedings of the Ninth International Conference on Permafrost, University of Alaska Fairbanks, June 29-July 3, edited by: Kane, D. L. and Hinkel, K. M., vol. 1, 1037-1042, 2008.

Le Moigne, J., Cole-Rhodes, A. A., Eastman, R. D., Netanyahu, N. S., Stone, H. S., Zavorin, I., and Morisette, J. T.: Multitemporal and multisensor image registration, in: Image Registration for Remote Sensing, edited by: Le Moigne, J., Netanyahu, N. S., and Eastman, R. D., Cambridge University press, chap. 14, 293-338, 2011.

Markus, T., Stroeve, J. C., and Miller, J.: Recent changes in Arctic sea ice melt onset, freezeup, and melt season length, J. Geophys. Res.-Oceans, 114, C12024, doi:10.1029/2009JC005436, 2009.

Mars, J. C. and Houseknecht, D. W.: Quantitative remote sensing study indicates doubling of coastal erosion rate in past $50 \mathrm{yr}$ along a segment of the Arctic coast of Alaska, Geology, 35, 583586, doi:10.1130/G23672A.1, 2007.

Maslanik, J., Stroeve, J., Fowler, C., and Emery, W.: Distribution and trends in Arctic sea ice age through spring 2011, Geophys. Res. Lett., 38, L13502, doi:10.1029/2011GL047735, 2011.

Morgenstern, A., Grosse, G., Günther, F., Fedorova, I., and Schirrmeister, L.: Spatial analyses of thermokarst lakes and basins in Yedoma landscapes of the Lena Delta, The Cryosphere, 5, 849-867, doi:10.5194/tc-5-849-2011, 2011.

Opel, T., Dereviagin, A. Y., Meyer, H., Schirrmeister, L., and Wetterich, S.: Palaeoclimatic information from stable water isotopes of Holocene ice wedges on the Dmitrii Laptev Strait, Northeast Siberia, Russia, Permafrost Periglac., 22, 84-100, doi:10.1002/ppp.667, 2011.

Overduin, P. P., Hubberten, H.-W., Rachold, V., Romanovskii, N. N., Grigoriev, M. N., and Kasymskaya, M.: The evolution and degradation of coastal and offshore permafrost in the Laptev and East Siberian Seas during the last climatic cycle, in: Coastline Changes: Interrelation of Climate and Geological Processes, edited by: Harff, J., Hay, W., and Tetzlaff, D., The Geological Society of America Special Paper,
426, 97-111, doi:10.1130/2007.2426(07), 2007.

Overeem, I., Anderson, R. S., Wobus, C. W., Clow, G. D., Urban, F. E., and Matell, N.: Sea ice loss enhances wave action at the Arctic coast, Geophys. Res. Lett., 38, L17503, doi:10.1029/2011GL048681, 2011.

Peterson, B. J., Holmes, R. M., McClelland, J. W., Vorosmarty, C. J., Lammers, R. B., Shiklomanov, A. I., Shiklomanov, I. A., and Rahmstorf, S.: Increasing river discharge to the Arctic Ocean, Science, 298, 2171-2173, doi:10.1126/science.1077445, 2002.

Pieczonka, T., Bolch, T., and Buchroithner, M.: Generation and evaluation of multitemporal digital terrain models of the Mt. Everest area from different optical sensors, Int. Soc. Photogramme., 66, 927-940, doi:10.1016/j.isprsjprs.2011.07.003, 2011.

Ping, C.-L., Michaelson, G. J., Guo, L., Jorgenson, M. T., Kanevskiy, M., Shur, Y., Dou, F., and Liang, J.: Soil carbon and material fluxes across the eroding Alaska Beaufort Sea coastline, J. Geophys. Res., 116, G02004, doi:10.1029/2010JG001588, 2011.

Pipko, I. I., Semiletov, I. P., Pugach, S. P., Wåhlström, I., and Anderson, L. G.: Interannual variability of air-sea $\mathrm{CO}_{2}$ fluxes and carbon system in the East Siberian Sea, Biogeosciences, 8, 19872007, doi:10.5194/bg-8-1987-2011, 2011.

Pizhankova, E. I. and Dobrynina, M. S.: Dinamika poberezh'ya Lyakhovskikh Ostrovov - Rezultaty deshifrirovaniya aerokosmicheskikh snimkov (The dynamics of the Lyakhovsky Islands coastline - results of aerospace image interpretation), Kriosfera Zemli (Earth's Cryosphere), 14, 66-79, available at: http: //www.izdatgeo.ru/pdf/krio/2010-4/66.pdf, 2010.

Popov, A. I.: Regionalnaya Kriolitologiya (Regional Cryolithology), Moscow State University Publishing House, 1989.

Rachold, V., Grigoriev, M. N., Are, F. E., Solomon, S., Reimnitz, E., Kassens, H., and Antonow, M.: Coastal erosion vs riverine sediment discharge in the Arctic Shelf seas, Int. J. Earth Sci., 89, 450-460, doi:10.1007/s005310000113, 2000a.

Rachold, V., Grigoriev, M. N., and Bauch, H.: An estimation of the sediment budget in the Laptev Sea during the last 5000 years, Polarforschung, 70, 151-157, available at: http://epic.awi. de/28493/, 2000b.

Rachold, V., Are, F. E., Atkinson, D. E., Cherkashov, G., and Solomon, S. M.: Arctic Coastal Dynamics (ACD): an introduction, Geo-Mar. Lett., 25, 63-68, doi:10.1007/s00367-004-01879, 2003.

Raymond, P. A., McClelland, J. W., Holmes, R. M., Zhulidov, A. V., Mull, K., Peterson, B. J., Striegl, R. G., Aiken, G. R., and Gurtovaya, T. Y.: Flux and age of dissolved organic carbon exported to the Arctic Ocean: A carbon isotopic study of the five largest arctic rivers, Global Biogeochem. Cy., 21, GB4011, doi:10.1029/2007GB002934, 2007.

Razumov, S. O.: Permafrost as a factor of the dynamics of the coastal zone of the Russian East Arctic Seas, Oceanology, 50, 262-267, doi:10.1134/S0001437010020116, 2010.

Razumov, S. O. and Grigoriev, M. N.: Coastal erosion as a destabilizing factor of carbonate balance in the East Siberian Arctic seas, Kriosfera Zemli (Earth's Cryosphere), 15, 65-68, available at: http://www.izdatgeo.ru/pdf/krio/2011-4/65_eng.pdf, 2011.

Romanovskii, N. N. and Tumskoy, V. E.: Retrospektivnyi podkhod k ocenke sovremennogo rasprostraneniya i stroeniya shelfovoi kriolitozony vostochnoi Arktiki (Retrospective approach to the 
estimation of the contemporary extension and structure of the shelf cryolithozone in East Arctic), Kriosfera Zemli (Earth's Cryosphere), 15, 3-14, available at: http://www.izdatgeo.ru/pdf/ krio/2011-1/3.pdf, 2011.

Romanovskii, N., Hubberten, H.-W., Gavrilov, A., Tumskoy, V., Tipenko, G., Grigoriev, M., and Siegert, C.: Thermokarst and land-ocean interactions, Laptev Sea Region, Russia, Permafrost Periglac., 11, 137-152, doi:10.1002/10991530(200004/06)11:2<137::AID-PPP345>3.0.CO;2-L, 2000.

Romanovsky, V. E., Drozdov, D. S., Oberman, N. G., Malkova, G. V., Kholodov, A. L., Marchenko, S. S., Moskalenko, N. G., Sergeev, D. O., Ukraintseva, N. G., Abramov, A. A., Gilichinsky, D. A., and Vasiliev, A. A.: Thermal state of permafrost in Russia, Permafrost Periglac., 21, 136-155, doi:10.1002/ppp.683, 2010.

ROSHYDROMET and ArcticRIMS: Lena at Kusur, stream discharge station data, available at: http://rims.unh.edu/data/station/ station.cgi?station=6342, 2009.

RSG: Remote Sensing Software Graz, software documentation, release 7.03, Institute for Digital Image Processing of Joanneum Research, Graz, Austria, 2011.

Santoro, M. and Strozzi, T.: Circumpolar digital elevation models $>55^{\circ} \mathrm{N}$ with links to geotiff images, ESA DUE Permafrost, DEM from Russian Topographic Maps, doi:10.1594/PANGAEA.779748, 2012.

Schirrmeister, L., Grosse, G., Kunitsky, V., Magens, D., Meyer, H., Dereviagin, A., Kuznetsova, T., Andreev, A., Babiy, O., Kienast, F., Grigoriev, M., Overduin, P. P., and Preusser, F.: Periglacial landscape evolution and environmental changes of Arctic lowland areas for the last 60000 years (western Laptev Sea coast, Cape Mamontov Klyk), Polar Res., 27, 249-272, doi:10.1111/j.1751-8369.2008.00067.x, 2008.

Schirrmeister, L., Grosse, G., Wetterich, S., Overduin, P. P., Strauss, J., Schuur, E. A. G., and Hubberten, H.-W.: Fossil organic matter characteristics in permafrost deposits of the northeast Siberian Arctic, J. Geophys. Res., 116, G00M02, doi:10.1029/2011JG001647, 2011a.

Schirrmeister, L., Kunitsky, V., Grosse, G., Wetterich, S., Meyer, H., Schwamborn, G., Babiy, O., Derevyagin, A., and Siegert, C.: Sedimentary characteristics and origin of the Late Pleistocene Ice Complex on north-east Siberian Arctic coastal lowlands and islands - a review, Quaternary Int., 241, 3-25, doi:10.1016/j.quaint.2010.04.004, 2011b.

Sekretov, S. B.: Eurasian Basin - Laptev Sea geodynamic system: tectonic and structural evolution, Polarforschung, 69, 5154, available at: http://epic.awi.de/28453/, 2001.

Semiletov, I. P., Pipko, I. I., Shakhova, N. E., Dudarev, O. V., Pugach, S. P., Charkin, A. N., McRoy, C. P., Kosmach, D., and Gustafsson, Ö.: Carbon transport by the Lena River from its headwaters to the Arctic Ocean, with emphasis on fluvial input of terrestrial particulate organic carbon vs. carbon transport by coastal erosion, Biogeosciences, 8, 2407-2426, doi:10.5194/bg8-2407-2011, 2011.

Shiklomanov, N. I., Streletskiy, D. A., and Nelson, F. E.: Northern Hemisphere component of the Global Circumpolar Active Layer Monitoring (CALM) Program, in: Proceedings of the Tenth International Conference on Permafrost, Salekhard, Yamal-Nenets Autonomous District, Russia, 25-29 June 2012, edited by: Hinkel, K. M., vol. 1, International Contributions,
377-382, The Northern Publisher, Salekhard, 2012.

Shur, Y., Vasiliev, A., Kanevskiy, M., Maximov, V., Pokrovsky, S., and Zaikanov, V.: Shore Erosion in Russian Arctic, in: Cold regions Engineering - Cold Regions Impacts on Transportation and Infrastructure, edited by: Merrill, K., American Society of Civil Engineers, 736-747, 2002.

Sisko, R. K.: Termoabrazionnye berega arkticheskikh morei - na primere o. Novaya Sibir (Thermo-abrasional coasts of arctic seas - on the example of the island of New Siberia), Glaciologicheskie issledovaniya $\mathrm{v}$ polyarnykh stranakh (glaciological research in polar regions), AANII, Leningrad, 294, 183-194, 1970.

Sohn, H. G., Kim, G.-H., and Yom, J.-H.: Mathematical modelling of historical reconnaissance CORONA KH-4B imagery, Photogramm Rec, 19, 51-66, doi:10.1046/j.0031868X.2003.00257.x, 2004.

Sovershaev, V. A.: Beregovaya zona arkticheskikh morei (Coastal zone of Arctic Seas), in: Geoekologiya Severa (Geoecology of the North), edited by: Solomatin, V. I., Moscow State University Publishing House, Moscow, chap. 2.5, 55-59, 1992.

Strauss, J. and Schirrmeister, L.: Permafrost sequences of Buor Khaya Peninsula, in: Russian-German Cooperation System Laptev Sea: The Expedition Eastern Laptev Sea - Buor Khaya Peninsula 2010, edited by: Wetterich, S., Overduin, P. P., and Grigoriev, M. N., vol. 629, Reports on Polar and Marine Research, Alfred-Wegener-Institute, chap. 5, 35-50, available at: http://epic.awi.de/29931/, 2011.

Strauss, J., Schirrmeister, L., Wetterich, S., Borchers, A., and Davydov, S. P.: Grain-size properties and organic-carbon stock of Yedoma Ice Complex permafrost from the Kolyma lowland, northeastern Siberia, Global Biogeochem. Cy., 26, GB3003, doi:10.1029/2011GB004104, 2012.

Streletskaya, I. D., Kanevskiy, M. Z., and Vasiliev, A. A.: Massive ground ice in dislocated quaternary sediments of Western Yamal, Kriosfera Zemli (Earth's Cryosphere), 10 (2), 68-78, available at: http://www.izdatgeo.ru/pdf/krio/2006-2/68.pdf, 2006.

Thieler, E. R., Himmelstoss, E. A., Zichichi, J. L., and Ergul, A.: Digital Shoreline Analysis System (DSAS) version 4.0 - an ArcGIS extension for calculating shoreline change, US Geological Survey Open-File Report 2008-1278, 2009.

Toutin, T.: Review article: geometric processing of remote sensing images: models, algorithms and methods, Int. J. Remote Sens., 25, 1893-1924, doi:10.1080/0143116031000101611, 2004.

Treshnikov, A. F.: Atlas Arktiki. (Atlas of the Arctic.), National Commission of Hydro-Meteorology and Environmental Protection, Major Dept. of Geodesy and Cartography, Moscow, 1985.

Ulrich, M., Morgenstern, A., Günther, F., Reiss, D., Bauch, K. E., Hauber, E., Rössler, S., and Schirrmeister, L.: Thermokarst in Siberian ice-rich permafrost: comparison to asymmetric scalloped depressions on Mars, J. Geophys. Res., 115, E10009, doi:10.1029/2010JE003640, 2010.

Van Huissteden, J., Berrittella, C., Parmentier, F. J. W., Mi, Y., Maximov, T. C., and Dolman, A. J.: Methane emissions from permafrost thaw lakes limited by lake drainage, Nat. Clim. Change, 1, 119-123, doi:10.1038/nclimate1101, 2011.

Vasiliev, A. A., Streletskaya, I. D., Shirokov, R. S., and Oblogov, G. E.: Coastal permafrost evolution of western Yamal in context of climate change, Kriosfera Zemli (Earth's Cryosphere), 15, 63-65, available at: http://www.izdatgeo.ru/pdf/krio/2011-4/ 
63_eng.pdf, 2011.

Vonk, J. E., Sánchez-García, L., van Dongen, B. E., Alling, V., Kosmach, D., Charkin, A., Semiletov, I. P., Dudarev, O. V., Shakhova, N., Roos, P., Eglinton, T. I., Andersson, A., and Gustafsson, Ö.: Activation of old carbon by erosion of coastal and subsea permafrost in Arctic Siberia, Nature, advance online publication, 489, 137-140, doi:10.1038/nature11392, 2012.

Wassmann, P.: Arctic marine ecosystems in an era of rapid climate change, Prog. Oceanogr., 90, 1-17, doi:10.1016/j.pocean.2011.02.002, 2011.

Wetterich, S. and Schirrmeister, L.: Limnological studies in the Dmitrii Laptev Strait region, in: Russian-German Cooperation System Laptev Sea: The Expedition Lena - New Siberian Islands 2007 during the International Polar Year 2007/2008, edited by: Boike, J., Bolshiyanov, D. Y., Schirrmeister, L., and Wetterich, S., vol. 584, Reports on Polar and Marine Research, Alfred Wegener Institute, chap. 5.2, 155-163, available at: http: //epic.awi.de/28775/, 2008.
Wetterich, S., Schirrmeister, L., Andreev, A. A., Pudenz, M., Plessen, B., Meyer, H., and Kunitsky, V. V.: Eemian and Late Glacial/Holocene palaeoenvironmental records from permafrost sequences at the Dmitry Laptev Strait (NE Siberia, Russia), Palaeogeogr. Palaeocl., 279, 73-95, doi:10.1016/j.palaeo.2009.05.002, 2009.

Wetterich, S., Overduin, P. P., and Grigoriev, M. N. (Eds.): RussianGerman Cooperation System Laptev Sea: The Expedition Eastern Laptev Sea - Buor Khaya Peninsula 2010, vol. 629, Reports on Polar and Marine Research, Alfred Wegener Institute, available at: http://epic.awi.de/29931/, 2011.

Whitehouse, P. L., Allen, M. B., and Milne, G. A.: Glacial isostatic adjustment as a control on coastal processes: an example from the Siberian Arctic, Geology, 35, 747-750, doi:10.1130/G23437A.1, 2007.

Winterfeld, M., Schirrmeister, L., Grigoriev, M. N., Kunitsky, V. V., Andreev, A., Murray, A., and Overduin, P. P.: Coastal permafrost landscape development since the Late Pleistocene in the western Laptev Sea, Siberia, Boreas, 40, 697-713, doi:10.1111/j.15023885.2011.00203.x, 2011. 